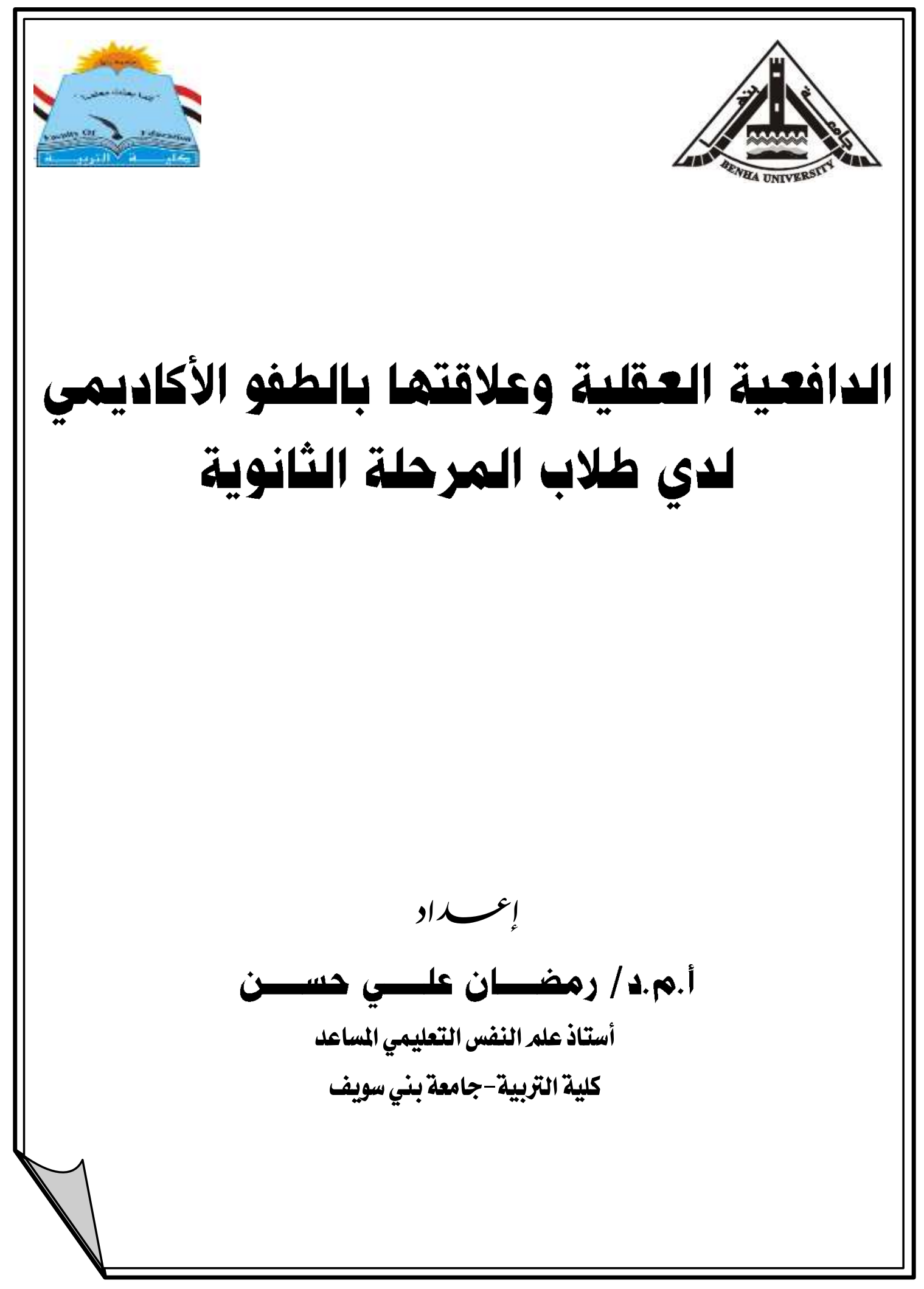




\section{الدافعية العقلية وعلاقتها بالطفو الأكاديمي لدي طلاب المرحلة الثانوية}

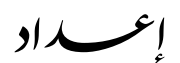

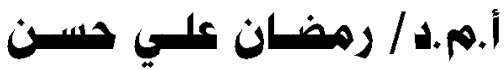

أستاذ علم النفس التعليمي المساعد

كلية التربية-جامعة بني سويف الميفي

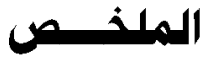

هدف البحث إلي التعرف علي العلاقة بين الطفو الأكاديمي والدافعية العقلية لدي طلاب الصف الثاني الثانوي، وتكونت عينة البحث من ( . . r) طالباً وطالبة من طلاب الصف الثاني الثانوي بمحافظة بني سويف، وتم استخدام المنهج الوصفي؛ لملاءمته لطبيعة وأهداف البحث، واستخدم البحث مقياس الطفو الأكاديمي إعداد (2016) Piosang ترجمة "الباحث"، ومقياس الدافعية العقلية إعداد "الباحث"، وتوصلت النتائج إلي وجود علاقة إرتباطية إيجابية دالة إحصائياً بين الدافعية العقلية وبين أبعاد الطفو الأكاديمي (الفاعلية الذاتية، الاندماج الأكاديمي، العلاقة بين المعلم والطالب)، ووجود علاقة إرتباطية سلبية دالة إحصائياً بين الدافعية العقلية وبين أبعاد الطفو الأكاديمي (السيطرة غير المؤكدة، القلق)، كما توصلت النتائج إلي عدم وجود فروق ذات دلالية إحصائية في الدافعية العقلية بين الذكور والإناث، ووجود فروق ذات دلالة إحصـائية في الطفو الأكاديمي بين الذكور والإناث، ووجود فروق ذات دلالة إحصـائية بين متوسطي درجات مرتقعي ومنخفضي الأداء علي مقياس الدافعية العقلية في الطفو الأكاديمي، كما توصلت النتائج إلي أنه يمكن التبؤ بالطفو الأكاديمي من خلال الدافعية العقلية. الكلمات المفتاحية: الدافعية العقلية، الطفو الأكاديمي، طلاب الصف الثاني الثانوي. 


\section{Mental Motivation and Its Relationship to Academic Buovancy among Secondary School Students}

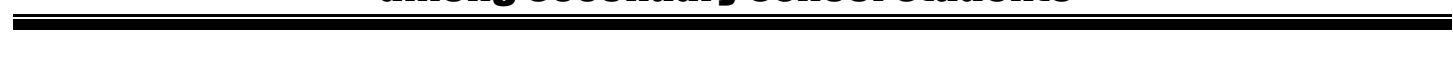

\section{Abstract}

The current research aimed at identifying the relationship between academic buoyancy and mental motivation among secondary second grade students. The research sample consisted of (200) secondary second grade students in Beni-Suef Governorate. Descriptive approach was used to suit its nature and objectives of the research. The research used the academic buoyancy Scale (Piosang preparation (2016) and "researcher" translation), and Scale of mental motivation(researcher preparation). The results showed the existence of statistically significant positive correlation between mental motivation and the dimensions of academic buoyancy (self-efficacy, academic integration, the relationship between the teacher and the student), and the existence of statistically significant negative correlation between mental motivation and the dimensions of academic buoyancy(Unconfirmed control, anxiety). the results also found that there were no statistically significant differences in mental motivation between males and females, and the existence of statistically significant differences in academic buoyancy between males and females, and the existence of statistically significant differences between means of scores of students with high performance and students with low performance on Mental motivation scale in academic buoyancy, and the results also found that academic buoyancy can be predicted through mental motivation.

Key words: Mental Motivation, AcademicBuoyancy, secondary second grade students. 
يُعد الطالب محور العملية التربوية وعليه تبنى الآمال والتطلعات المستقبلية للمجتمع، ومن المعروف أن القدرات التي يتميز بها الإنسان قابلة للنمو والتطور، وتحثنا على التقدم بطلابنا

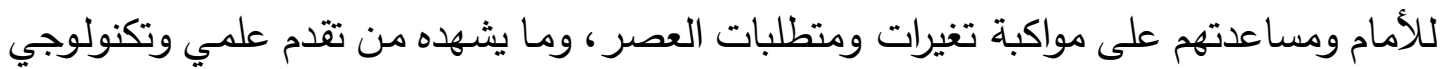

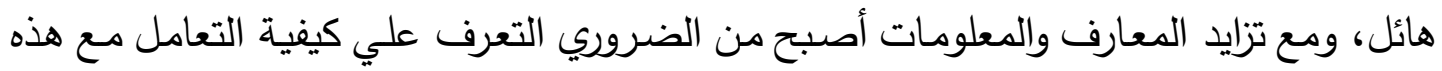

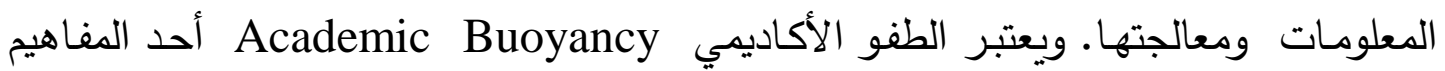
الحديثة في علم النفس الايجابي، والذي يركز علي النواحي الايجابية في شخصية الطالب،

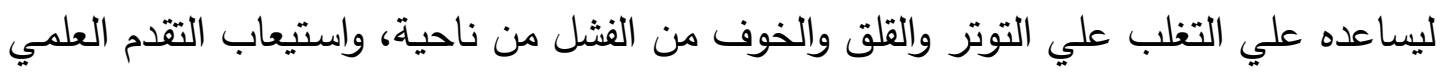

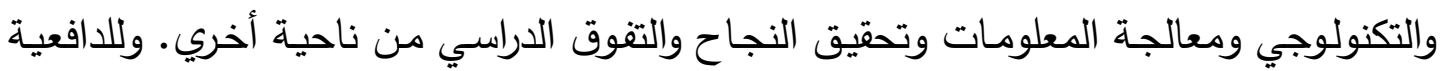

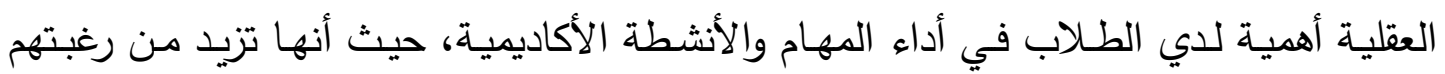
وقدراتهم وثقتهم بأنغسهم في إتمام تلك المهام والأنثطة.

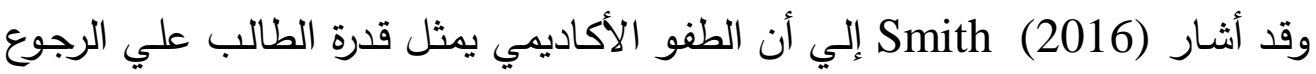

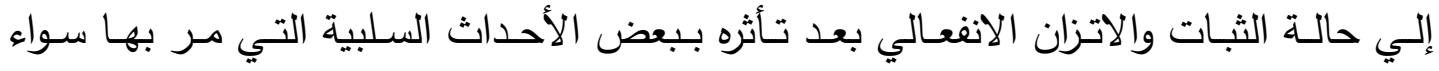

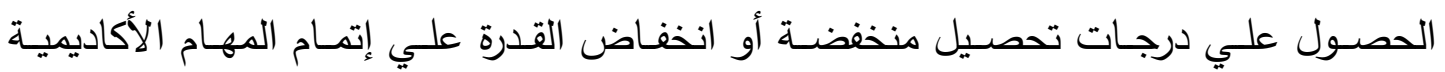
المطلوبـة منـه. وأشـار (Martin,Yu, Ginns, \& Papworth 2017) إلي أن الطفو النو الأكاديمي يمثل قدرة الطالب علي الاستجابة الفعالة للعقبات والصعوبات الأكاديمية التي تواجهه

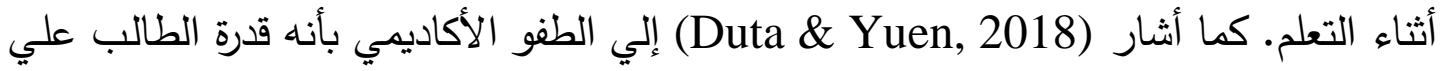
التعامل مع مشكلات الدراسة اليومية والتي ترتبط بالأداء والإنجاز الأكاديمي.

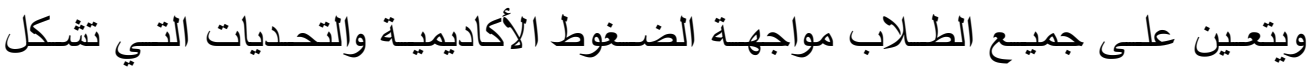

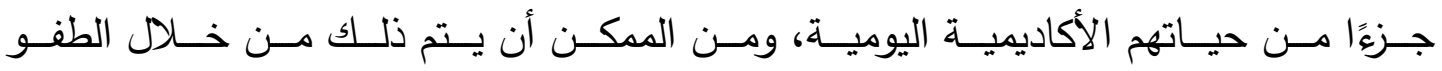

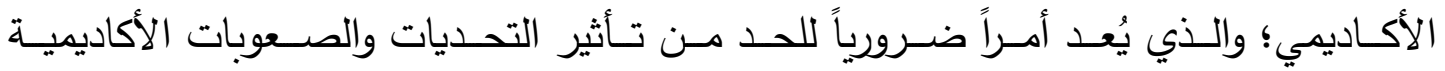
.(Rohinsa, Cahyadi, Djunaidi \& Iskandar, 2019) وللطفو الأكاديمي أثر فعال في تحسين الصحة العقلية والنفسية بالإضافة إلي تحسين الرفاهية النفسية، وهذا ما أشارت إليه نتائج بحث (2019) Anderson، ويرتبط ارتباط موجب بمفهوم الذات الأكاديمي والأداء الأكاديمي لدي طلاب المدارس، حيث كلما التها ارتفع مستوي الطفو الأكاديمي كلما

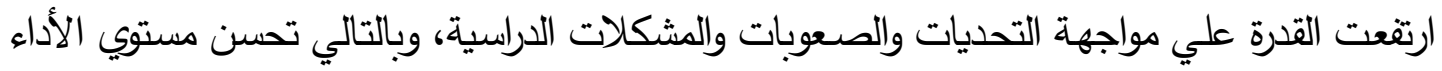


الأكاديمي، الأمر الذي ينعكس بثكل ايجابي علي مفهوم الذات الأكاديمي وسمات الثخصية والكفاءة

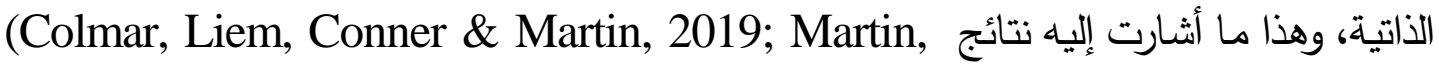
Hou, Osborn, Yu \& Zhan, 2019; Rohinsa, et al., 2019; Rosemary, Wawire \& (نoyne, 2019)

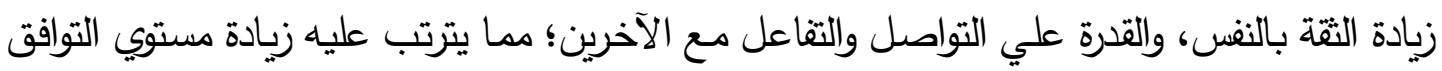

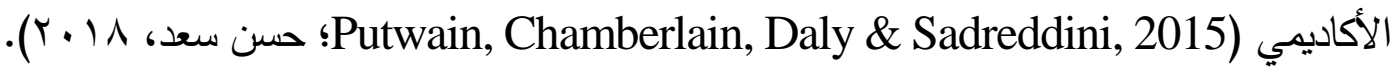

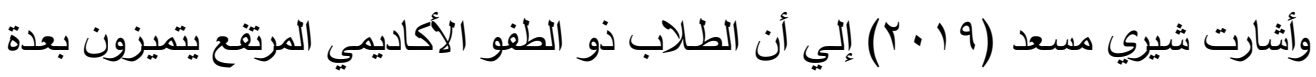

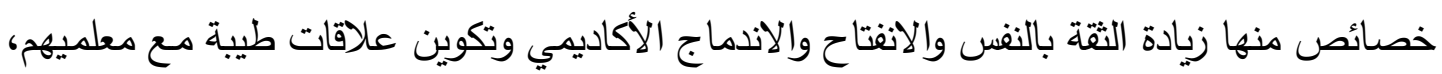
مما يساهم في مواجهتهم للمن والصعوبات الأكاديمية، ومن ثم النجاح والتتوق الأكاديمي.

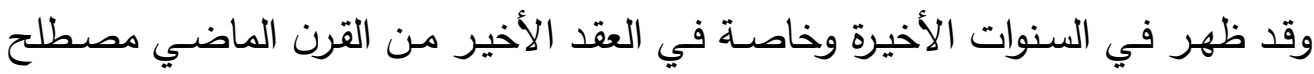
الدافعية العقلية، ويُعد كل من Giancarlo \& Facione أول من أعدا مقياساً للدافعية العقلية أسماه مقياس كاليفورنيا للدافعية العقلية (California Measure of Mental Motivation).

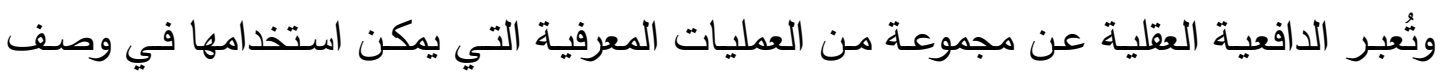
التفكير أثناء حل المشكلات واتخاذ القرار والسعي المستمر نحو التغيير والإبداع (Giancarlo)

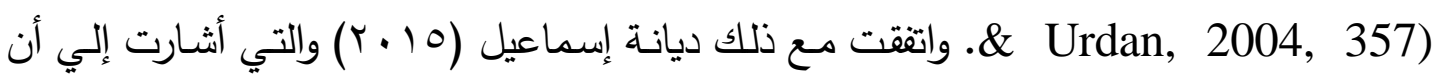

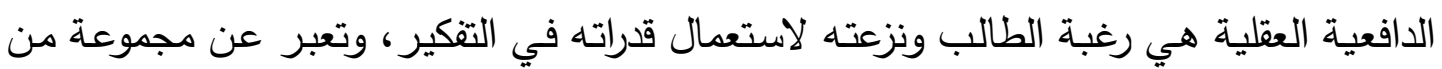
العمليات المعرفية التي يمكن أن تستعمل في حل المشكلات واتخاذ القرار .

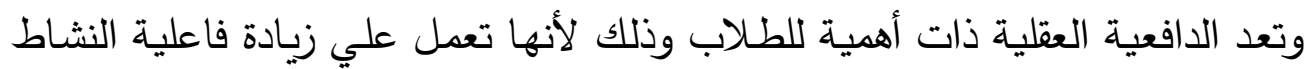

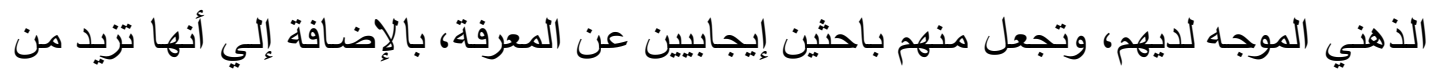

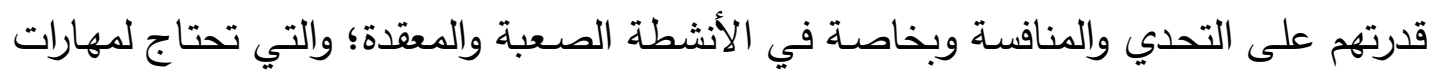

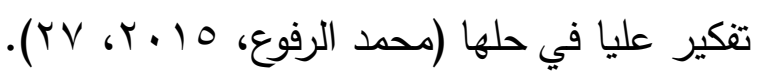

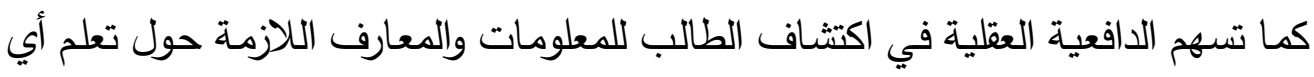
موضوع بهدف فهمه؛ وهذا يعزز الفاعلية الذاتية والثتة بالنفس لدياه، وكذلك القيام بالمهام التي يرغبها

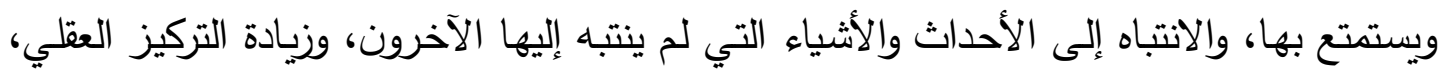

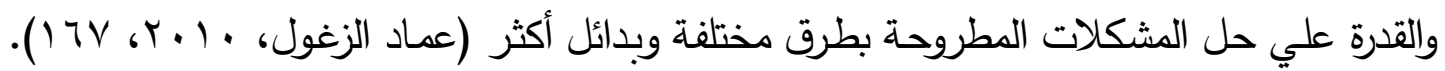

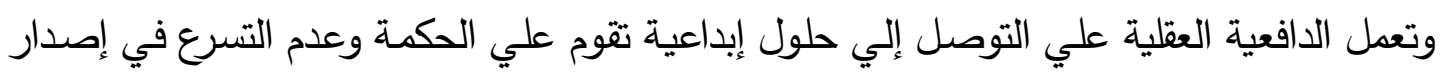

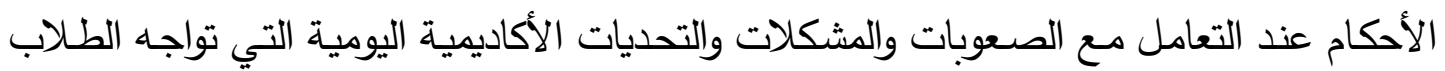


(عادل المنشاوي، 10 • ب). كما تعمل الدافعية العقلية علي توضيح الأفكار وإدراكها بدرجة أكبر، وتحقيق التتوع في التفكير وتوجيهه نحو أفكار جديدة ومنطقية (Heilat \& Seifert, 2019). وتعد الدافعية العقلية مؤشر فعال علي كفاءة التعلم الايجابية وهذا ما أشارت إليه دراسة

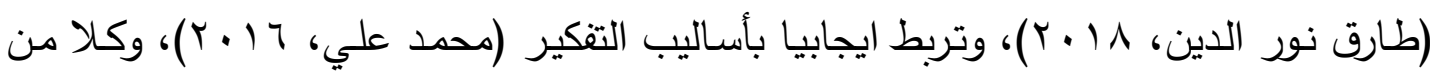

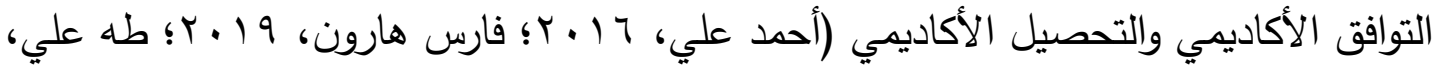

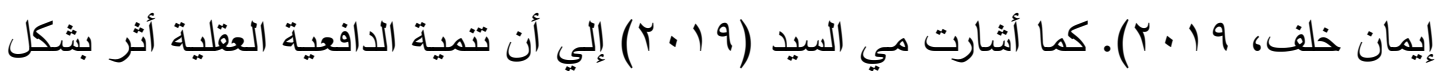
إيجابي علي اندماج الطلاب الأكاديمي داخل الأنشطة والمهام الأكاديمية.

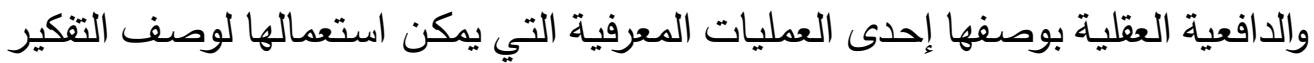

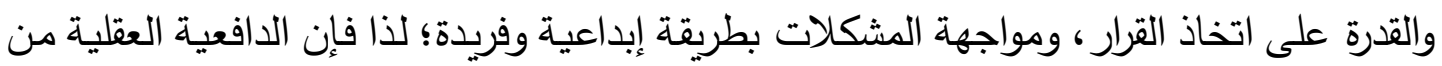

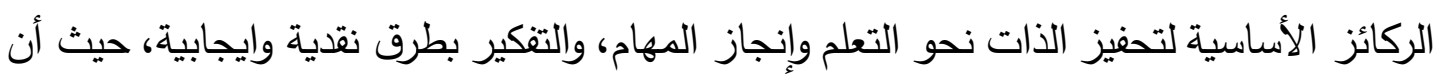

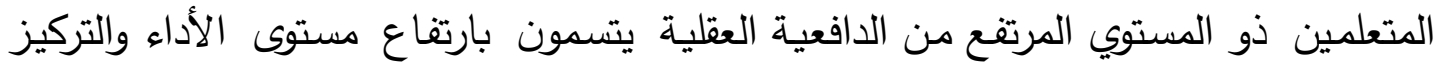

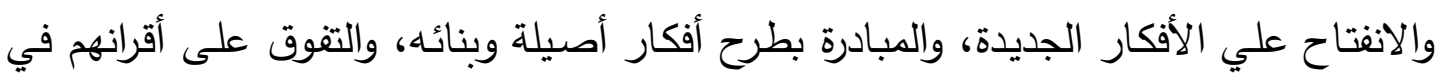

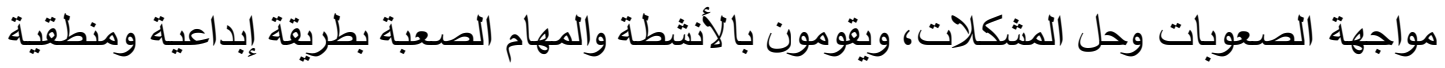

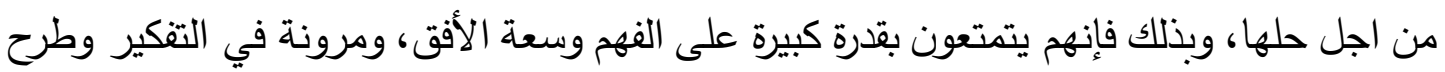

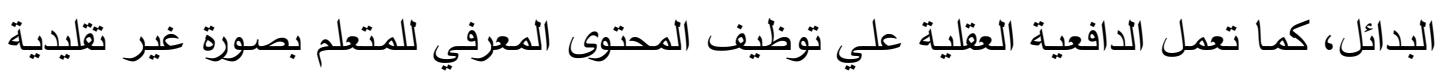

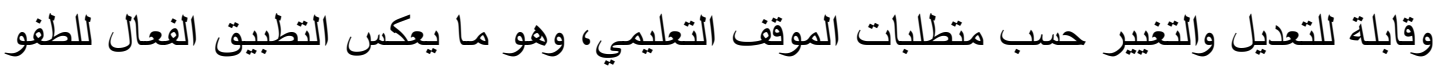
الأكاديمي، فالدافعية العقلية من المحركات الأساسية للتوظيف الفعال للطفو الأكاديمي.

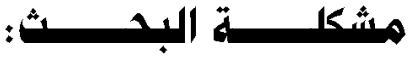

يتوقف مدى التقدم العلمي واكتثاف النظريات والاختراعات العلمية على ما يمتلكه الطلاب

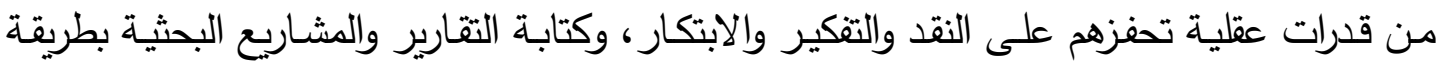

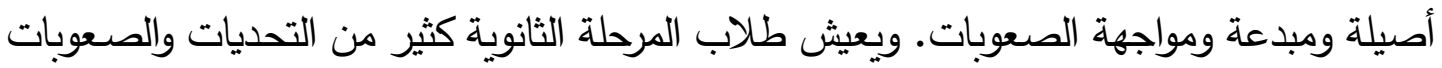

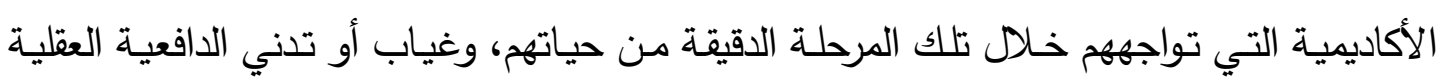

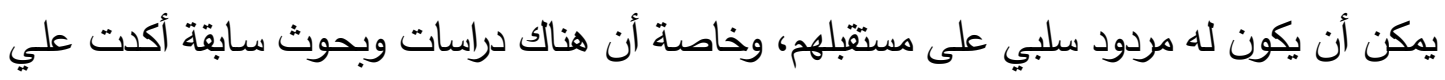
أن تدني الدافعية العقلية يجعل من المتعلم ذو عقلية جامدة، ويتبح طريقة تقليدية في التفكير ، بعيدا

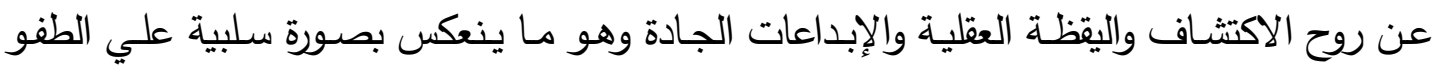
(Omaima, 2018; Alfonso \& Yang, 2019; الأكاديمي. وأشارت إلي ذلك نتائج دراسات الإنهات 
Martin et al., 2019)

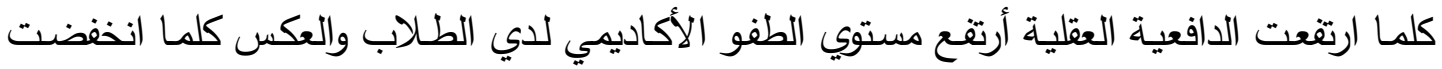
الدافعية العقلية انخفض الطفو الأكاديمي.

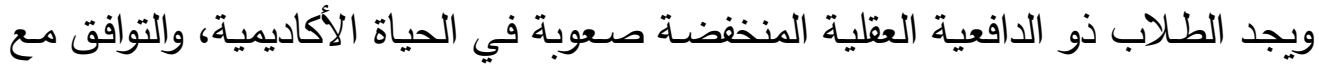
ضغوط الحياة الدراسية، وبالتالي ضعف مواجهتها، وتدني طرق حلها، وضعف القدرة على تحقيق التوازن النفسي واتخاذ القرار • وبما أن الدافعية العقلية يتم تحفيزها أثناء تهيئة أجواء دارسيه إيجابية

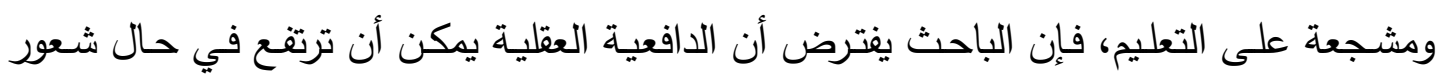

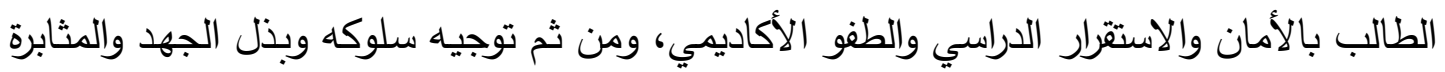

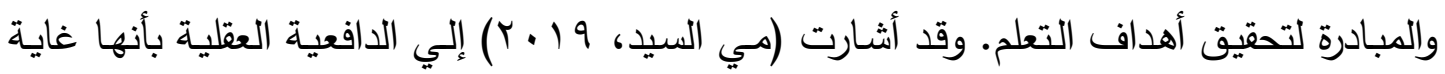

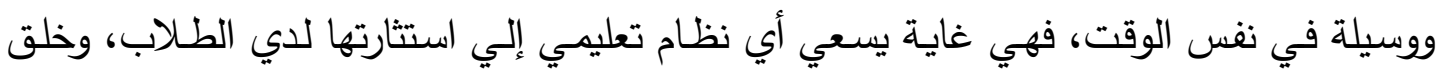

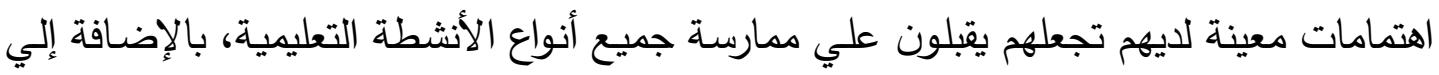
أنها وسيلة لتحقيق العديد من الأهداف التربوية التي تسعي إليها المؤسسات. وهناك اختلاف في نتائج بعض الدراسات والبحوث السابقة التي تتاولت الدافعية العقلية منها نتائج (Heilat \& Seifert, 2019)، وكذلك نتائج بحث فارس هارون (19 ( ب) والتي

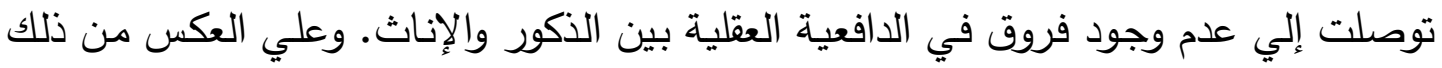

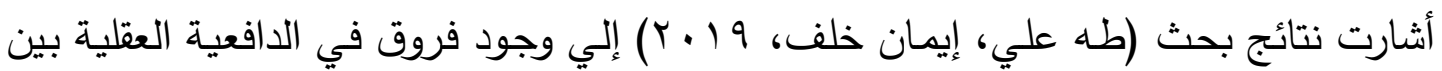
الذكور والإناث لصالح الإناث.

وأشار Putwain, Connors, Symes, \& Douglas-Osborn (2012) إلي أن الأن الناش الطفو الأكاديمي يساعد الطلاب على التعامل مع المخاطر الأكاديمية. هذا بالإضـافة إلي أنه

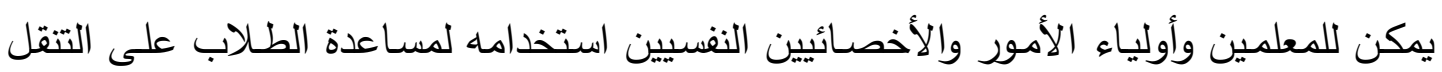

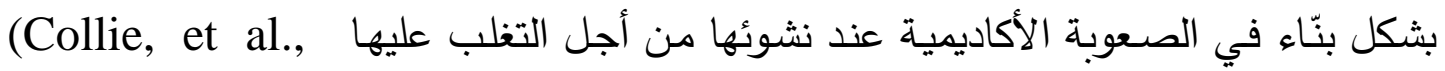

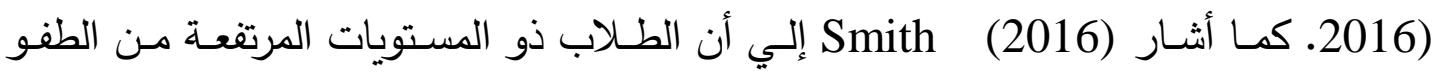

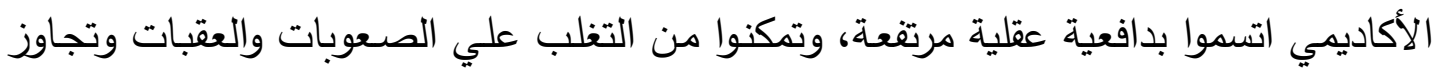

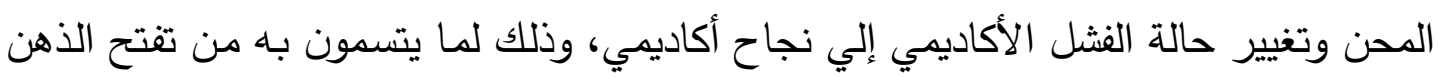

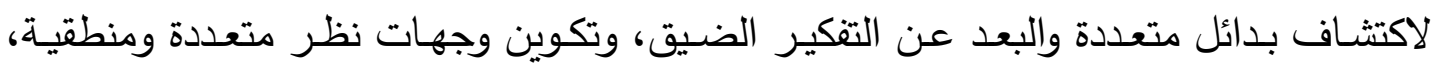

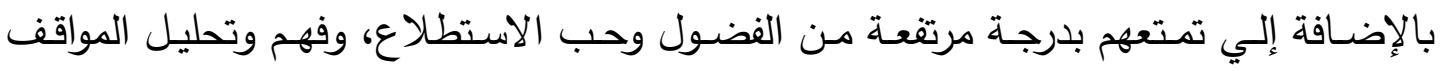

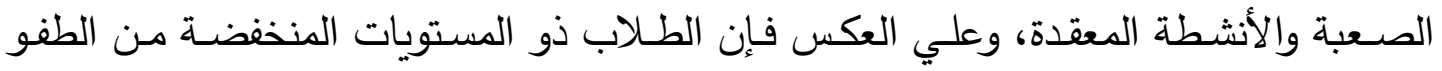


الأكـاديمي اتسموا بدافعيـة عقليـة منخفضـة، وبالتـالي الجمود الفكري والتمسك بطريقـة واحدة وتقليدية ونمطية عند التفكير في مواجهة التحديات والصعوبات الأكاديمية.

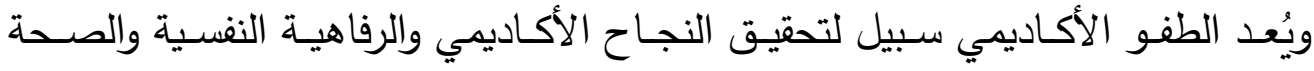
النفسية والعقلية وذلك من خلال قدرة الطالب علي التعامل مـع عدد كبير من التحديات التي يواجهها باستمرار خلال حياته الدراسية (Duta \& Yuen, 2018; Anderson, 2019). (Collie, Martin, ويرتبط الطفو الأكاديمي ارتباطاً ايجابياً بالمساندة الاجتماعية (Rosemary, et al., والكفاءة الذاتية الأكاديمية، Malmberg, Hall \& Ginns, 2017)

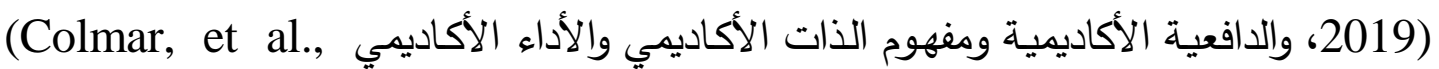
(2019، وسمات الثخصية (Rohinsa, et al., 2019)، والدافعية العقلية والإنجاز الأكاديمي، (Smith, 2016; ويعد كلا من الطفو الأكاديمي والدافعية العقلية منبأن بالإنجاز الأكاديمي Omaima, 2018; Shafi, Hatley, Millican \& Templeton, 2018; Alfonso \& Wurf \& Groft-Piggin كما أكدت نتائج بحث .Yang, 2019; Martin et al., 2019) (2015) علي أهمية كل من الدافعية العقلية، والاندماج الأكاديمي كأحد أبعاد الطفو الأكاديمي

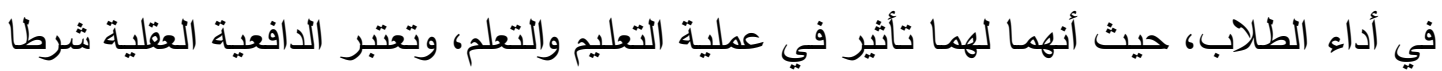
أساسيا في حدوث الاندماج الأكاديمي، ويتضح ذلك عند قيام الطالب بوضع هدف طويل المدي لنفسه مثل النجاح في المرحلة الثانوية والحصول علي درجات تحصيل مرتفعة، تجده يبذل جهد كبير لتحقيق ذلك الهدف، ويندمج في الأنثطة المختلفة التي تحقق له ذلك. وهنالك تتاقض في نتائج دراسـات وبحوث سـابقة تتاولت الطفو الأكاديمي منها نتائج

(Martin, Colmar, Darey \& Marsh, 2010; Rosemary, et al., 2019; Safoura \& (التي توصلت إلي عدم وجود فروق في الطفو الأكاديمي بين الذكور والإناث. (Shafi, et al., 2018; Martin \& Marsh, وعلي العكس من ذلك توصلت نتائج (2019 إلي وجود فروق في الطفو الأكاديمي بين الذكور والإناث لصالح الإناث. في حين (Collie, et al., 2016; Datu \& Yang, 2016 Mawarni, توصلت نتائج بحث Sugandhi, Budiman \& Thahir, 2019) الطفو الأكاديمي بين الذكور والإناث لصالح الذكور . 
وبالرغم من جهود الباحثين في دراسة الدافعية لما لها من أثر قوي وحيوي في التعلم بصفة خاصة وفي الحياة بصفة عامة، والتي أخذت مجالا واسعا في الدراسات والبحوث التربوية الأجنبية والعربية، إلا أن الجهود ما زالت قليلة في دراسة الدافعية العقلية رغم أنها تثير نثاط الطالب وحماسه وثقته بنفسه وتركيزه العقلي، بما يؤدي إلي زيادة قدرته علي مواجهة المشكلات التي تواجهه.

اتضح من السابق أن الدافعية العقلية تسهم في اكتساب العديد من القدرات والمهارات المتنوعة، والتي يمكن توظيفها في مواقف متباينة، كما أنها تدعم الإبداع وإذا كنا نسعى إلى متعلم

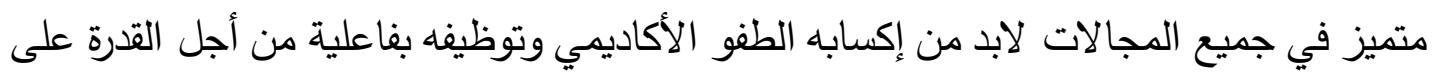
إنتاج الكثير من الحلول المبتكرة للمشكلات المختلفة، ولتحقيق ذلك لابد من توافر مجموعة من العوامل لعل أهمها الدافعية العقلية.

وفي ضوء ما سبق من نتائج بعض البحوث والدراسات السابقة التي تناولت الدافعية العقلية من جهة والطفو الأكاديمي من جهة أخري والدافعية العقلية وعلاقتها بالطفو الأكاديمي من جهة ثالثة، والتي كان هناك اختلاف في نتائج البعض منها، يمكن تحديد مشكلة البحث الحالي في التساؤلات التالية:

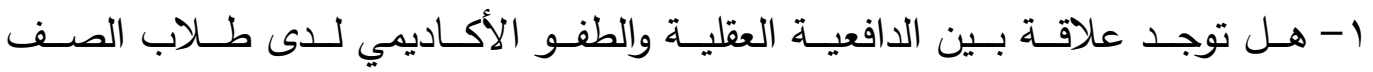
الثاني الثانوي؟

ץ- هـل توجد فـروق في الدافعيـة العقليـة بـين (الذكور - الإنـاث) للـى طـلاب الصـف الثاني الثانوي؟

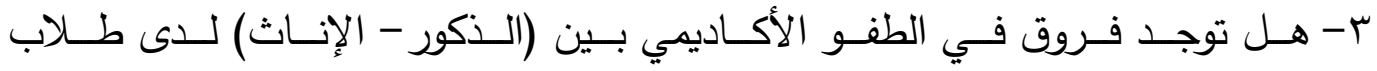
الصف الثاني الثانوي؟ - (الثان ـ - هل توجد فروق بين متوسطي درجات مرتفعي/ منخفضي الدافعية العقلية في الطفو الأكاديمي لدي طلاب الصف الثاني الثانوي. ه- هـلـ يمكـن التتبـؤ بـالطفو الأكـاديمي مـن خـلال الدافعيــة العقليـة لـدى طــلاب

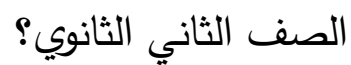


يمكن تحديد أهداف البحث فيما يلي: البه

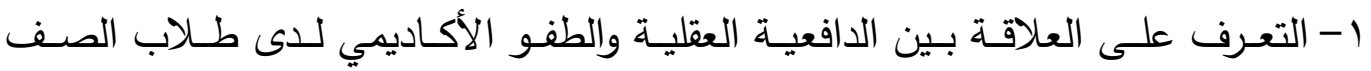

الثاني الثانوي.

r- الكثف عن الفروق في الدافعية العقلية بين (الذكور - الإناث) لدى طـلاب الصف

$$
\text { الثاني الثانوي. }
$$

r- الكثف عن الفروق في الطفو الأكاديمي بين (الذكور - الإناث) لدى طلاب الصف

$$
\text { الثاني الثانوي. }
$$

ع - التعرف علي الفروق بين متوسطي درجات مرتفعي/ منخفضسي الدافعية العقلية في العي

الطفو الأكاديمي لدي طلاب الصف الثاني الثانوي.

0- التتبؤ بالطفو الأكاديمي من خلال الدافعية العقلية لدى طلاب الصف الثاني الثاني الثانوي.

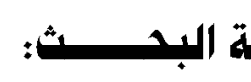

يكتسب البحث الحالي أهميته من خلال ما يلي:

\section{أولا: الأهميــة النظـــــــة}

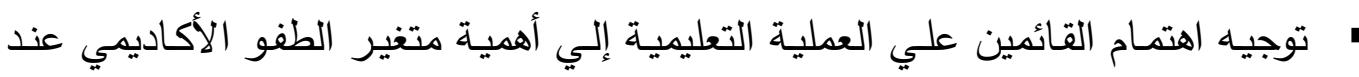

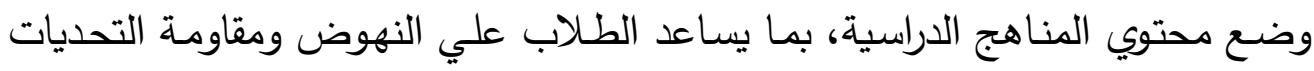

$$
\text { والصعوبات الأكاديمية. }
$$

• أهمية متغيرات البحث الحالي وطريقة تتاولها والأهداف البحثية المرجوة منها كما أن

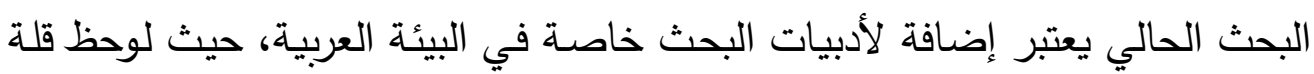

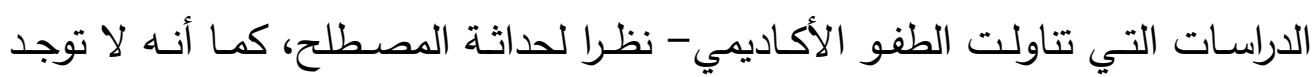
دراسة عربية في حدود علم الباحث تتاولت الدافعية العقلية وعلاقتها بالطفو الأكاديمي لاي طلاب الصف الثانوي. تبرز أهمية البحث من أهمية العينـة التي تتناولها البحث وهم طـلاب الصف الثاني الثانوي والذين يطبق عليهم نظام التعليم الجديد سواء في محتوي المناهج أو استخدام التكنولوجيا في أداء الامتحانات. 


\section{ثانياً: الأهميـــة التطبيقيـــــة :}

• ت تصميم مقياس الدافعية العقلية، وترجمة مقياس الطفو الأكاديمي (Piosang, 2016) وحساب الخصائص السيكومترية لكل منهما، بما يثكل فائدة للمكتبة العربية بتزويدها بتلك المقاييس وإتاحتها للباحثين في دارساتهم المستتبلية.

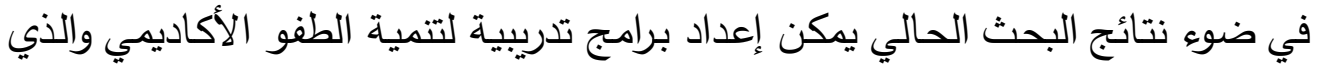
قد ينعكس أثره بشكل ايجابي على الدافعية العقلية.

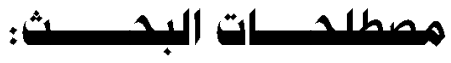

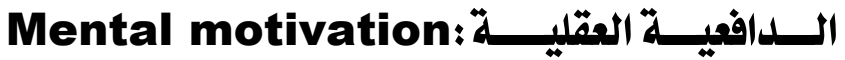

هي حالة داخلية تحفز عقل الطالب وتوجه تركيزه العقلي نحو حل المشكلات التي تواجهه

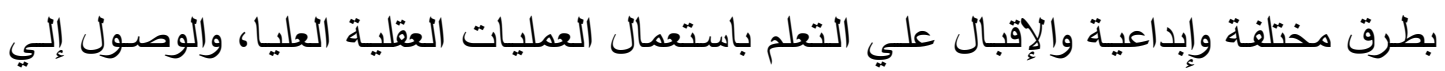

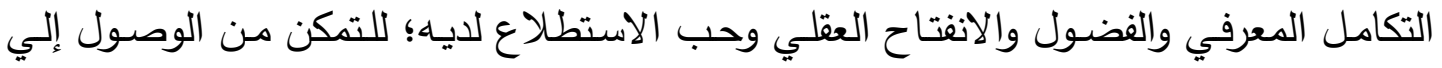

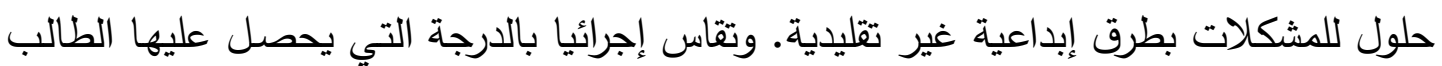

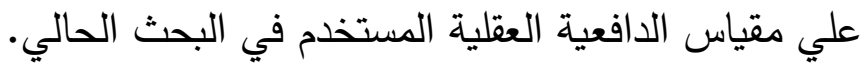

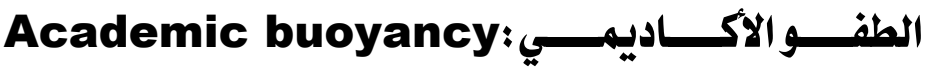

عرف Piosang(2016 الطفو الأكاديمي بأنه قدرة الطالب في الحفاظ علي كفاءته

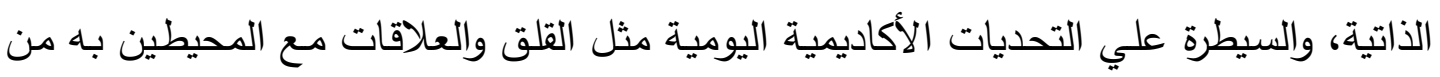

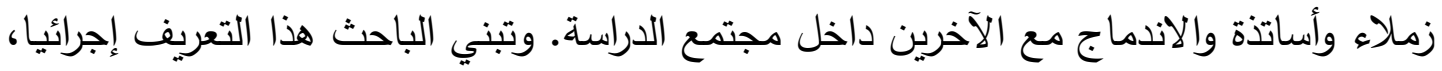
ويقاس الطفو الأكاديمي إجرائيا بمقياس الطفو الأكاديمي المستخدم في البحل البحث الحالي.

\section{الإطار النظري ودراسات وبدوث سابقة} تم تناول الإطار النظري ودراسات وبحوث سابقة من خلال التالي:

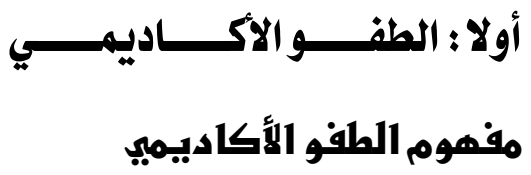

عرف Martin \& Marsh (2009) الطفو الأكاديمي بأنه قدرة الطلاب على التغلب بنجاح على النكسات والتحديات الأكاديمية في الحياة اليومية مثل انخفاض الدافعية، والأداء

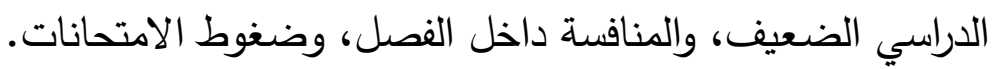




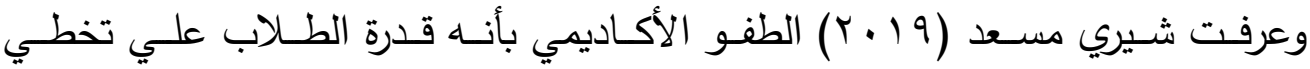

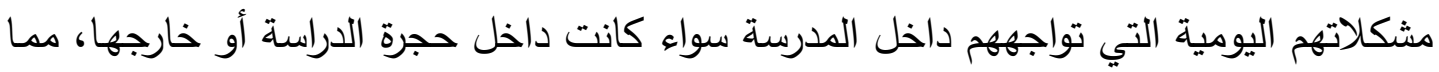

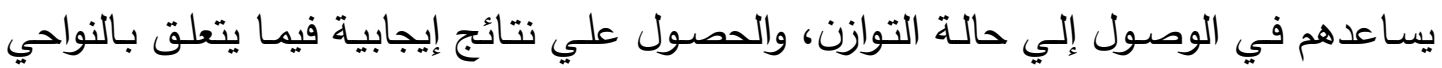

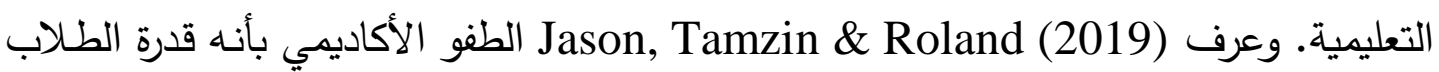
على اجتياز التحديات اليومية التي تمثل نمط الحياة المدرسية بنجاح.

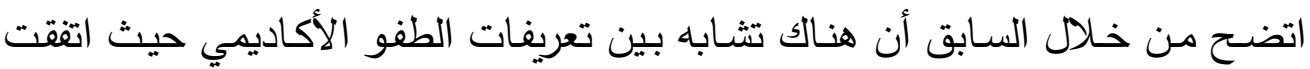

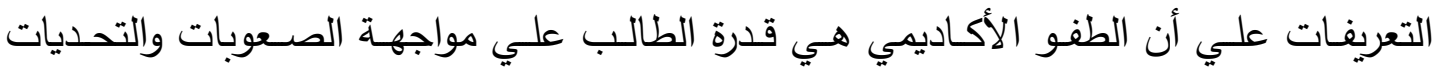
والمشكلات اليومية. وقد تبني الباحث مفهوم (Piosang, 2016).

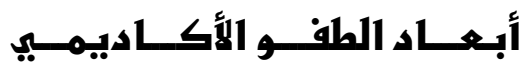

أثار Piosang (2016) إلي أن أبعاد الطفو الأكاديمي يمكن توضيحها فيما يلي: الفاعلية الذاتية: Self-Efficacy : يقصد بها قدرة الطلاب علي الفهم والأداء الجيد للمهام الأكاديمية، وبذل أقصي ما في وسعهم لمواجهة التحديات وأداء المهام. السيطرة غير المؤكدة: Uncertain Control أي عدم تأكد الطلاب من كيفية أداء المهام بشكل مناسب. الققق: Anxiety أي الإحساس بالتوتر وعدم الارتياح عند التفكير في أداء المهام الأكاديمية

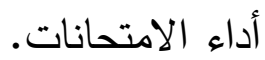

الاندماج الأكاديمي: Academic Engagement أي الاشتراك والاندماج والتتمع والمثابرة في أداء المهام الأكاديمية. العلاقة بين المعلم والطالب: Teacher-Student Relationship أي العلاقات بين الطلاب والمعلم وطريقة تواصلهم مع معلمهم واحترام معلمهم لهم.

\section{الفرق بين الطفو الأكاديمي والصمود الأكاديمير}

أشار (2009) Martin \& Mash إلي توضيح الفرق بين الطفو الأكاديمي والصمود

$$
\text { الأكاديمي فيما يلي: }
$$

• يشير الطفو الأكاديمي إلي أداء مدرسي ضعيف، بينما يشير الصمود الأكاديمي إلي

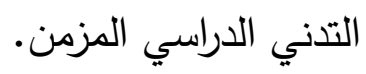


يشير الطفو الأكاديمي إلي ضعف الرغبة في المشاركات الصفية بينما يشير الصمود

$$
\text { الأكاديمي إلي الهروب من المدرسة ورفضها. }
$$

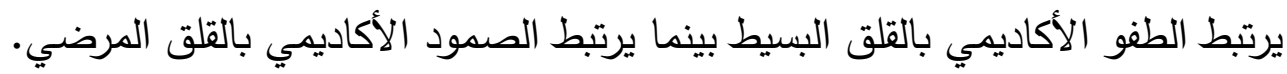

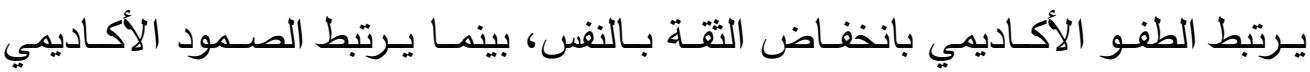

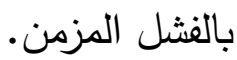

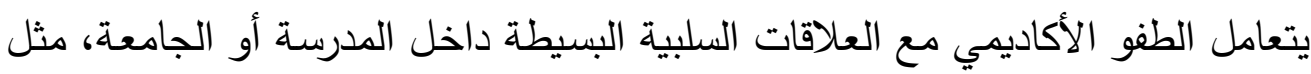

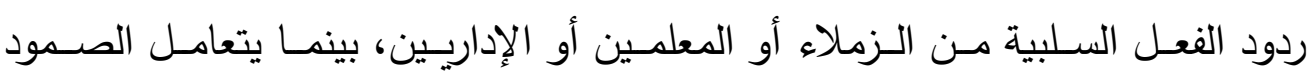

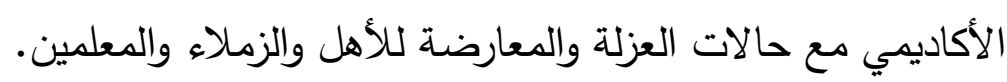

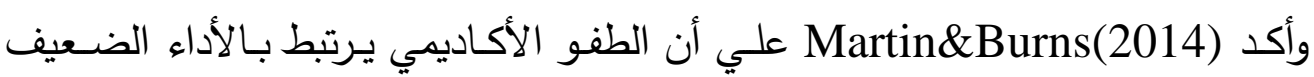

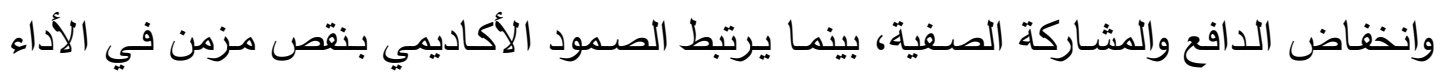
والاستياء والغضب والتغيب من المدرسة. اتضـح من خـلال السابق أن الطفو الأكاديمي ذو صلة ولة وثيقة بالإخفاقات والتحديات

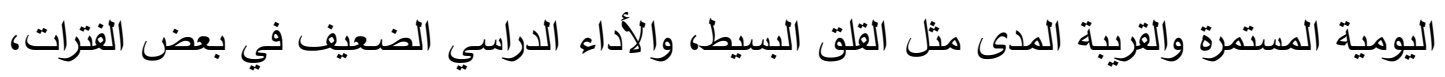

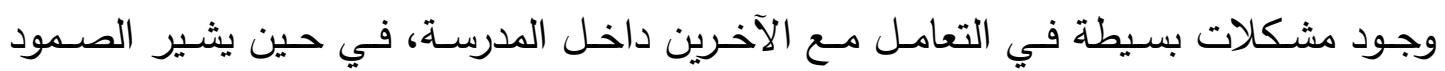

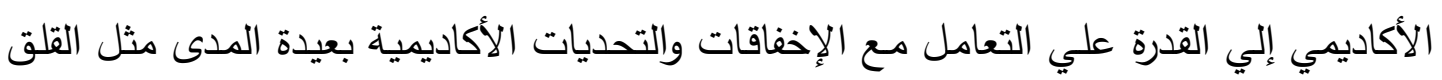
المزمن، والأداء الدراسي المتدني، ووجود مشكلات وصعوبات حادة في التعامل مـع الآخرين

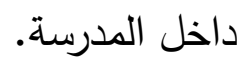

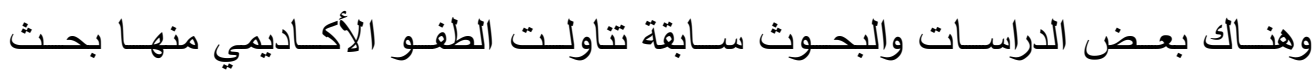

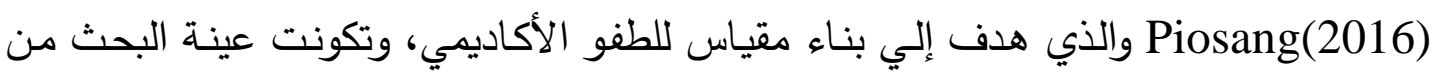

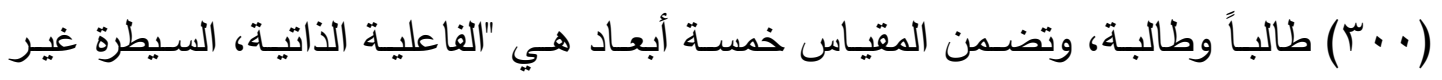

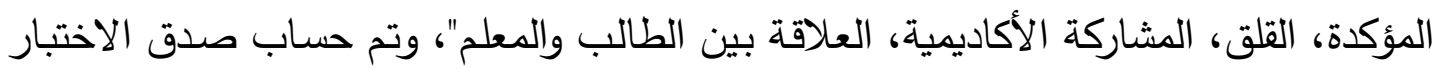

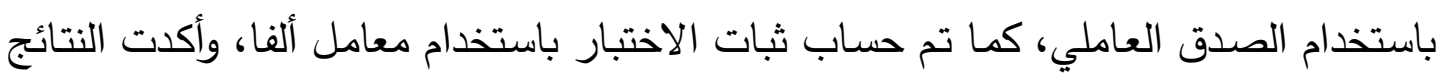
مناسبة المقياس لقياس الطفو الأكاديمي. وهدف بحث (2017) Collie, et al., إلي التعرف علي العلاقة بين المساندة

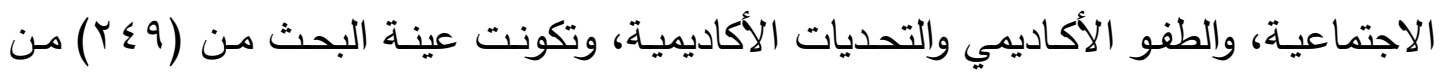

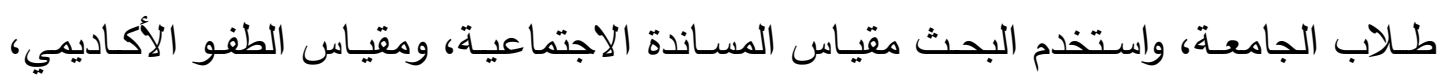

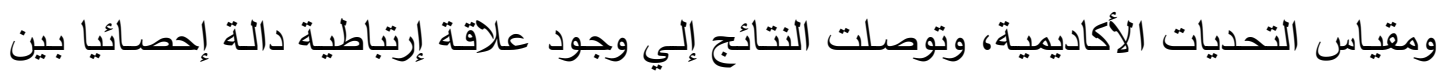


الطفو الأكاديمي والمساندة الاجتماعية والتحديات الأكاديمية، كما توصلت النتائج إلي وجود فروق في الطفو الأكاديمي بين الذكور والإناث لصالح الذكور •

وهدف بحث (Anderson(2019) إلي التعرف علي أثر الطفو الأكاديمي في تحسين الرفاهية النفسية والصـحة العقلية لدي طـلاب الجامعـة، وتكونت عينـة البحث مـن (rr) مـن طلاب الجامعة، تم تقسيمهم إلي مجموعتي إحداهما تجريبية وعددهم (7 ( ) والأخرى ضـابطة وعددهم (7 ( )، واستخدم البحث برنامج قائم علي الطفو الأكاديمي، ومقياس الرفاهية النفسية، وتوصلت نتائج البحث إلي وجود فروق دالة إحصائيا في الرفاهية النفسية والصحة العقلية بين القياسيين القبلي والبعدي لدي المجموعة التجربية لصالح القياس البعدي. وهدف بحث (2019) (Colmar, et al., إلي التعرف علي العلاقة بين الطفو الأكاديمي ومفهوم الذات الأكاديمي والأداء الأكاديمي، وتكونت عينة البحث من (19 (1) تلاميذ المرحلـة الابتدائيـة العليـا، واستخدم البحثث مقيـاس الطفو الأكاديمي، ومقيـاس مفهوم الذات الأكاديمي، ومقياس الأداء الأكاديمي في الرياضيات والقراءة، وتوصلت نتائج البحث إلي وجود

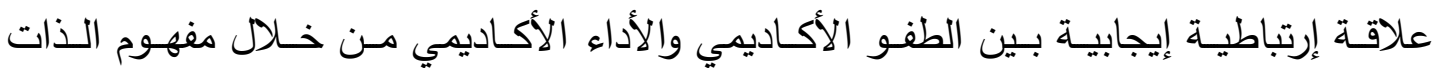
الأكاديمي كمتغير وسيط. وهدف بحث (2019) Martin \& Marsh إلي التعرف علي العلاقة بين الطفو الأكاديمي والتحديات الأكاديمية، وتكونت عينة البحث من (1) (1) من طلاب المدارس الثانوية، واستخدم البحث مقياس الطفو الأكاديمي، ومقياس التحديات الأكاديمية، وتوصلت النتائج إلي وجـود علاقـة إرتباطيـة بـين الطفـو الأكـاديمي والتحديات الأكاديميـة، وأنـه كلمـا ارتفـع الطفو الأكاديمي انخفضت التحديات الأكاديمية والعكس، كما توصلت النتائج إلي وجود فروق في الطفو الأكاديمي بين الذكور والإناث لصالح الإناث. كما هدف بحث (2019) Mawarni, et al., إلي دراسة الطفو الأكاديمي لدي طلاب

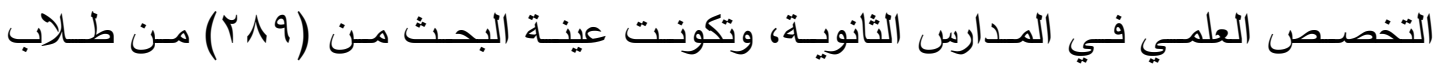
التخصص العلمي بالمرحلة الثانويـة، واستخدم البحث مقياس الطفو الأكاديمي، أظهرت نتائج البحث أن طلاب العلوم يحتاجون إلى طفو أكاديمي أعلى مقارنـة بالطلاب الآخرين ، ووجود فروق في الطفو الأكاديمي بين الذكور والإنـاث لصـالح الذكور ، ووجـود فروق في الطفو الأكاديمي بين طلاب السنة الأولي وطلاب السنة الثالثة لصالح طلاب السنة الثالثة. 
وهدف بحث (2019) Rohinsa, et al., إلي التعرف علي دور سمات الثخصية في

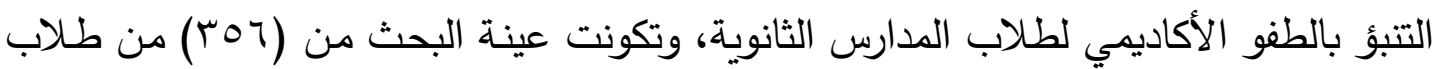

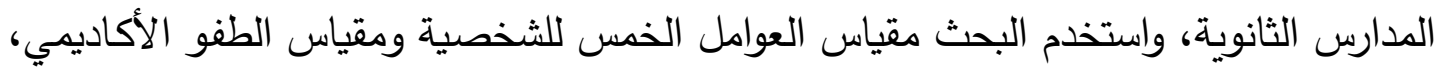

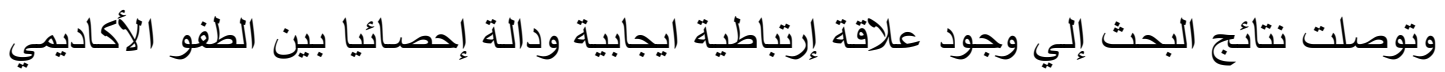

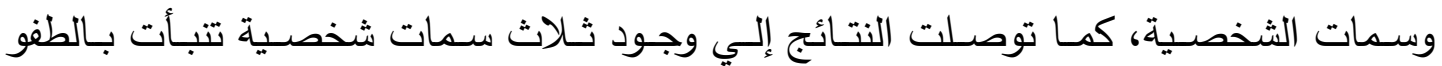
الأكاديمي بشكل إيجابي، وهي الوعي والالتزام والانبساط. وهدف بحث (2019) إلي التعرف علي العلاقة بين الطفو

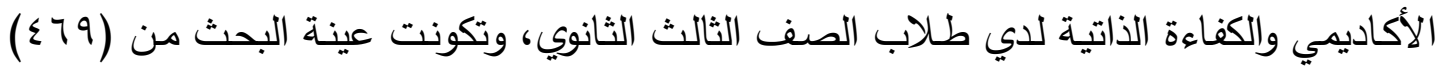

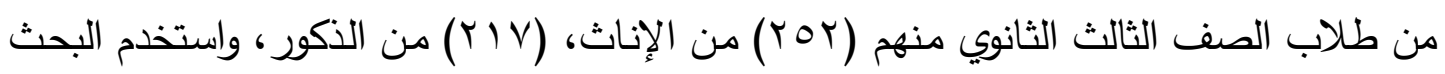

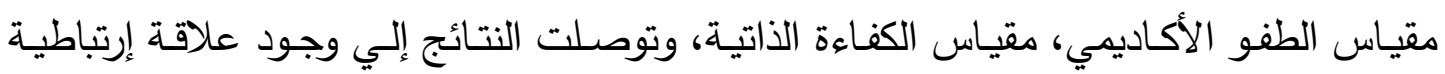

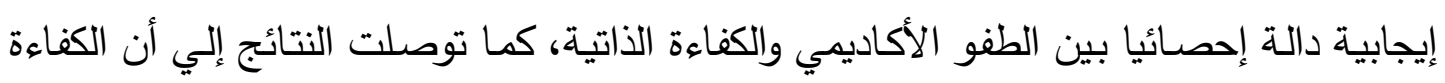
الذاتية تتبأت بالطفو الأكاديمي، وعدم وجود فروق في الطفو الأكاديمي بين الذكور والإناث. وهدف بحث (Safoura \& Behzad (2019) إلي التعرف علي الطفو الأكاديمي لدي

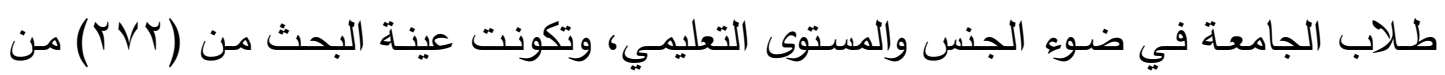

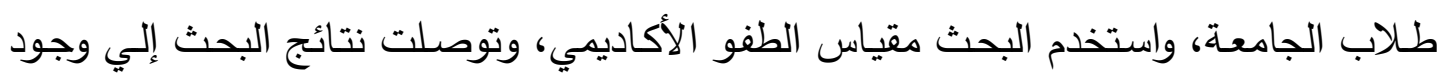
فروق في الطفو الأكاديمي بين طلاب الفرقة الأولي وطلاب الفرقة الرابعة في الطفو الألادي الأكاديمي

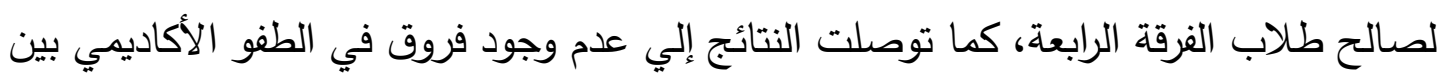

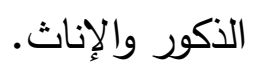

اتضح من خلال السابق وجود علاقة إرتباطية بين الطفو الأكاديمي وبعض المتغيرات الايجابية مثل الرفاهية النفسية والصحة العقلية والنفسية، والمساندة الاجتماعية والكفاءة الذاتية،

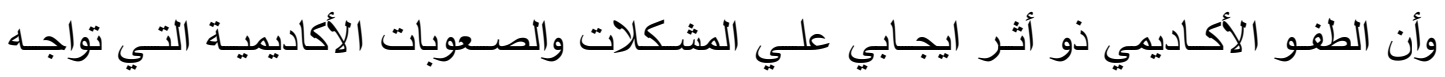

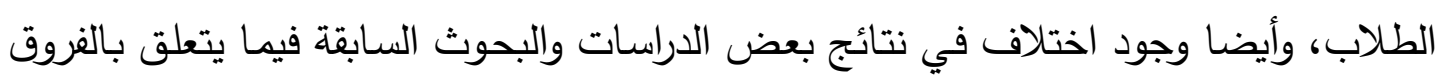

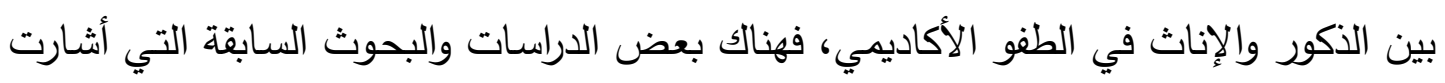

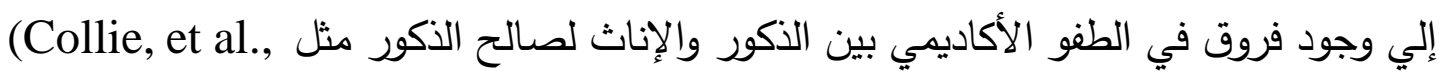

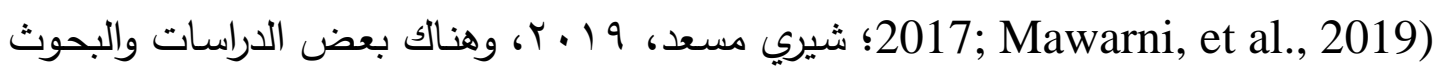
السابقة التي أشارت إلي وجود فروق في الطفو الأكاديمي بين الذكور والإناث لصالح الإناث مثل (Shafi, et al., 2018; Martin \& Marsh, 2019)، وهناك بعض الداديب لاسكات والبحوث 
السابقة التي أشـارت إلي عدم وجود فروق في الطفو الأكاديمي بين الذكور والإناث مثل .(Rosemary, et al., 2019; Safoura \& Behzad, 2019)

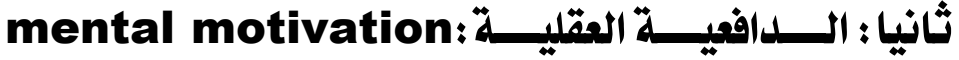

تُنىى الدافعية العقلية على افتراض أساسي هو أن جميع الطلاب لليهم القدرة على التثكير والقابلية لاستثارة الدافعية العقلية؛ لذا فلابد من تحفيز قدراتهم العقلية حتى يستخدموا دافعيتهم العقلية

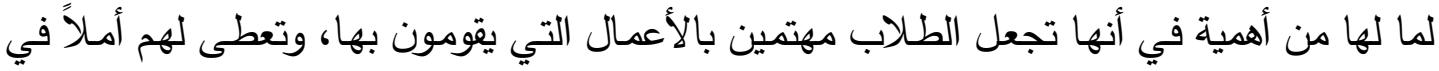
إيجاد أفكار جديدة هادفة وبناءه وذات قيمة. ويمكن تناول الدافعية العقلية من خلال التالي:

\section{مفهوم الدافعية العقلية:}

عرفها Giancarlo \& Facione (1998) على أنها حالة تؤهل صاحبها لإنجاز إبداعات جادة وطرائق متعددة لتحفيز هذه الحالة أو لحل المشكلات المطروحة بصورة مختلفة.

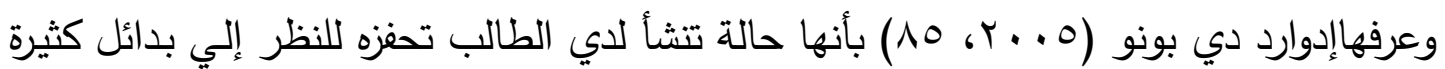

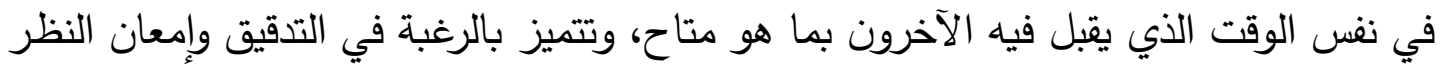

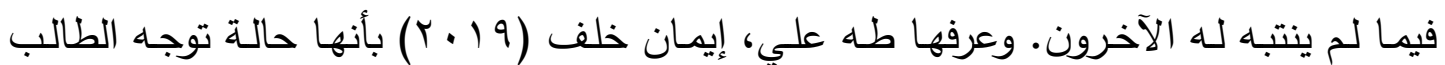
لاتخاذ القرار المناسب نحو موقف تعليمي معين يصاحبه نوع من الرضـا والارتياح. وعرفها

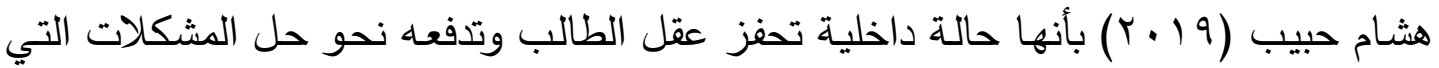
تواجهه، أو تقييم المواقف، واتخاذ القرار بشأنها أو إصدار الحكم عليها، باستعمال العمليات العقلية العليا، وتعبر عن رغبته للتفكير ، حيث تتسم بالثبات؛ والتي تجعل منها عادة عقلية لدى الدى الطالب، ويقابل الدافعية العقلية الجمود العقلي، والذي يشير إلى الطرق التقليدية باعتبارهـا أفضل طرق أو ربما تكون الوحيدة لعمل الأشياء.

\section{النماذج المفسرة للدافغية العقلية}

إن أهم النظريات والنماذج المفسرة للدافعية بصفة عامة والدافعية العقلية بصفة خاصة

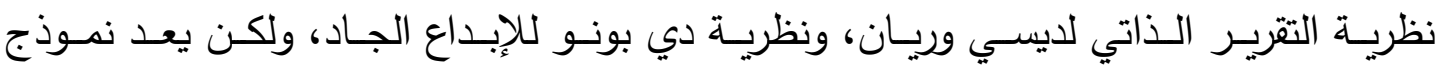

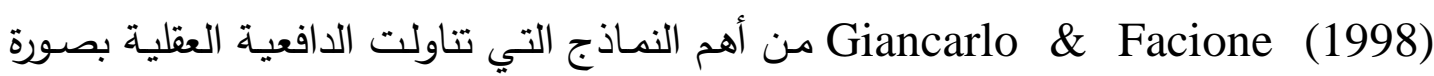
مباشرة، ونتج عن هذا النموذج ظهور مقياس كاليفورنيا للدافعية العقلية، وأشار هذا النموذج إلى الى الع العياه وجود أبعاد رئيسية للدافعية العقلية وهي: 


\section{أبـعاد الدافهبة العقلبة:}

\section{Mental Focus البعد الأول: التركيز العقلي}

يتصف المتعلم الذي يتميز بالقدرة على التركيز بأنه مثابر لا تضعف همته وتركيزه، ومنظم في عمله، وينجز أعماله في الوقت المحدد، ويركز في المهام التي يقوم بها، والصورة

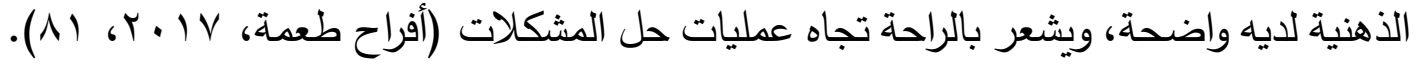
والتركيز العقلي يمثل نزعة المتعلم نحو الإتقان والتتظيم والمنهجية في مواجهة المهام وحل المشكلات، والثقة بالنفس في قدرته على إتمام المهام المطلوبـة في وقتها المحدد وبصورة دقيقة وواضـحة، ويتكون التركيز العقلي من الانتباه والتتظيم والثـعور بالراحة أثثاء استعمال العمليات العقلية (قيس محمد، وليد سالم, ع ا • ب، ع ع).

\section{Learning Orientation البعد الثاني: التوجه نحو التعلم}

يتمثل في قدرة الطالب على توليد دافعية عقلية داخلية لزيادة قاعدة المعلومات لديه،، ويتخذها وسيلة لتحقيق السيطرة على المهام الأكاديمية التي تواجهه في المواقف المختلفة، وتوليد دافعية عقلية خارجية تمكنه من الانخراط في عملية التعلم، والاندماج في أنشطة التحدي والمنافسة مع أقرانه، ولديه نزعة تجاه الحصول على المعلومة كإستراتيجية شخصية عند حل

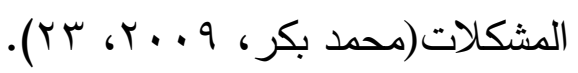

ويستدل علي التوجه نحو التعلم من خلال النظر إلى العوامل النفسية التي تسيطر على المتعلم، والتي تؤثر عليه وعلى أداءه وتتمثل فيما يلي: الاستثمار العاطفي للطالب أثثاء التعلم والأداء.

$$
\text { • التوجه الذاتي. }
$$

\section{Creative Problems Solving البعد الثالث: الحل الابداعى للمشكلات} يتمثل في القدرة على حل المشكلات بأفكار وحلول إبداعية وأصيلة، ويظهر ذلك الإبداع من خلال الرغبة في الانخراط في الألغاز والأنشطة والمشكلات المعقدة، وهذه الرغبة تبرز التحدي البنّاء بين الطلاب، كما أن هؤلاء الطلاب لديهم إحساس قوي بالرضـا عن الذات وبصفة خاصة عند الانخراطفي أنشطة صعبة أكثر من المشاركة في أنشطة تبدو سهلة، ولديهم طرق

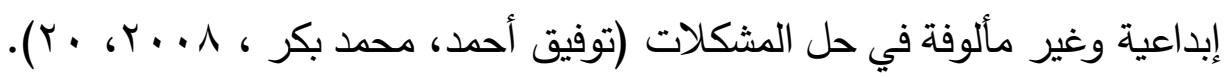




\section{البعد الرابع: التكامل المعرفي Cognitive Integrity}

إن الطلاب الذين يتميزون بالتكامل المعرفي يغلب عليهم السعي دائما والبحث لاكتساب المعلومات والمعارف الجديدة، كما يتميزون بالقدرة على التحدي ومواجهة المشكلات الصعبة، ويشعرون بالرضـا عند حلها، ويتمثل التكامل المعرفي في قدرة الطلاب على استخدام مهارات تفكير موضوعية تجاه جميع الأفكار ، وهذا ما أشار إليه "دي بونو" في نظريـة القبعات الستة التفكير تحت مسمى القبعة البيضاء، فهم طلاب يبحثون عن الحقيقة بشكل ايجابي، ذو ذهن متفتح، ويتقبلون وجهات النظر الأخرى، ويستمتعون بالتفكير خلال التفاعل مع الآخرين في

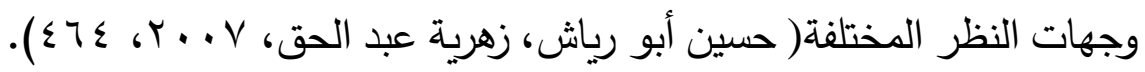

\section{البعد الخاصس: الفضول والانفتاح العقلي Open-mindedness}

يتمثل في قدرة الطالب على التكيف مـع المواقف المختلفـة والتعامـل مـع التحديات والصعوبات التي تواجهه, ويعد التفتح العقلي من أهم سمات المفكر الناقد، وهو صفة مكتسبة للطالب المفكر , والعقلية المتفتحة تتميز برغبة حقيقية في الاستماع إلى وجهات نظر الآخرين والانتباه إلي الحقائق جميعها بصرف النظر عن مصدرها، والاعتراف بالوقوع في الخطأ، وعدم التحيز إلى جانب أو حقيقة أو رأي على حساب آخر • (محمد علي، 7 ا • ب).

وأشار (Heilat \& Seifert, 2019) إلي أن الفضول العقلي هو الحافز إلى كل أشكال التعلم، وهو جوهر التفكير العلمي, ويتضمن طرح الأسئلة، والفضول وحب الاستطلاع، وهو أحد أشكال التعلم الموجها ذاتياً، وهو أيضـا الطريقـة الطبيعية للتعلم عندما يترك الطلاب كي

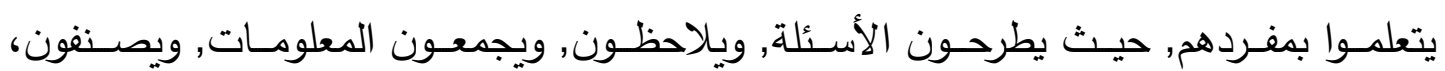
ويجربون, وينقلون ملاحظـاتهم, وأفكارهم إلى بعضـهم البعض، فهو مـن المهارات الضـرورية لتنمية التفكير الإبداعي والناقد.

وهناك بعض الدراسات والبحوث السابقة التي تتاولت الدافعية العقلية منها بحث محمد علي (T ( • r) والذي هدف إلى التعرف على درجة الدافعية العقلية وأساليب التفكير ، وتكونت عينة البحث من (YTM) طالبا وطالبة من طلاب الجامعة، واستخدم البحث مقياس كاليفورنيا للدافعية العقلية، وتوصلت النتائج إلي وجود علاقة إرتباطية إيجابية ذات دلالة إحصائية بين الدافعية العقلية وأسـاليب التفكير، كما توصلت النتائج إلي وجود فروق في بعد التركيز العقلي بين الذكور والإناث لصالح الإناث. 
وهدف بحث فـارس هـارون (9 ( ب ب) إلي التعرف علي العلاقـة بين الدافعيـة العقليـة والتوافق الأكاديمي لدى طلاب الدراسات العليا في جامعة القادية، وتكونت عينة البحث من ( • 1 ( ) طالبـا وطالبـة مـن كليـات جامعـة القادسية، واسـتخدم البحث مقيـاس الدافعيـة العقليـة ومقيـاس التوافق الأكاديمي، وتوصلت نتائج البحث إلي أن طـلاب الدراسـات العليا يتمتعـون بالدافعية العقلية، والتوافق الأكاديمي، ووجود علاقة إرتباطية إيجابية ذات دلالة إحصائية بين الدافعية العقلية والتوافق الأكاديمي. لائه وهدف بحث طـه علي، إيمـان خلف (9 ( ب ب) إلـي التعـرف علي أثر التقاعل بين الدافعيـة العقليـة والمعتقدات الرياضـية على التحصـيل الأكـاديمي لطـلاب كليـة التربيـة شـعبة الرياضيات، وتكونت عينة البحث من (V) • (r) طالب وطالبة بالفرقة الأولى شعبة الرياضيات بكلية التربية بسوهاج، واستخدم البحث مقياس الدافعية العقلية، ومقياس المعتقدات الرياضية، وتوصلت نتائج البحث إلي وجود علاقة إرتباطية بين الدافعية العقلية والمعتقدات الرياضية.، كما توصلت النتائج إلي وجود فروق ذات دلالة إحصائية في الدافعية العقلية بين الذكور والإناث لصـالح الإناث، كما توصلت النتائج إلي انخفاض الدافعية العقلية لدي طلاب الفرقة الأولي شعبة رياضيات.

وهدف بحث (Heilat \& Seifert, 2019) إلي التعرف علي العلاقة بين الدافعية العقلية ومصـادر الدعم العاطفي لدى المراهقين، وتكونت عينة البحث من (19) من المراهقين واستخدم البحث مقياس كاليفورنيا للدافعيـة العقلية، مقيـاس الدعم العاطفي، وتوصلت نتائج البحث إلي وجود علاقة إرتباطية بين الدافعية العقلية ومصـادر الدعم العاطفي، كما توصلت النتائج إلي وجود فروق في الدافعية العقلية بين الذكور والإناث لصالح الإناث. وهدف بحث حسن عطيه (9 1 • ( ) إلى التعرف على مستوى الدافعيـة العقليـة لدى الطلبة الموهوبين بمحافظـة جدة والفروق في تلك الدرجـة تبعاً لمغير الجنس، وتكونت عينـة البحث مـن ( . . ع) طالبـاً وطالبـة مـن الطـلاب الموهوبين في منطقـة جدة، واسـخدم البحث مقياس الدافعيـة العقلية المطور على البيئة السعودية ، وتوصلت نتائج البحث إلي أن درجـة الدافعية العقلية لاى الطلاب الموهوبين بمحافظة جدة كانت متوسطة، كما توصلت النتائج إلي وجـود فـروق ذات دلالــة إحصـائية بـين الذكور والإنـاث في بعدي التوجـه نــو التعلم وحل المشكلات إبداعياً والدرجة الكلية لصالح الإناث. 
وهدفت دراسة (2019) Yasmine إلي التعرف علي أثر الموسيقي في تحسين الدافعية

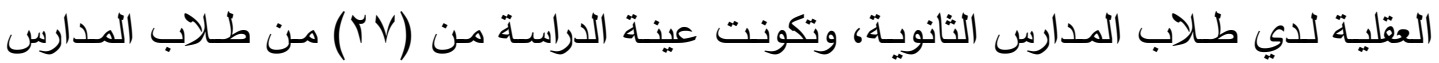

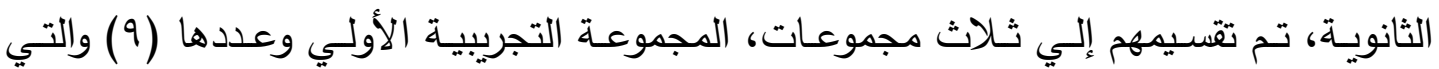
تعرضت للبرنامج التدريبي القائم علي الموسيقي، والمجموعة التجريبية الثانية وعددها (9) والتي

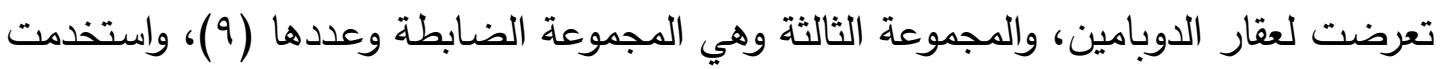
الدراسة مقياس الدافعية العقلية والبرنامج، وتوصلت النتائج إلي وجود فروق ذات دلالة إحصائية

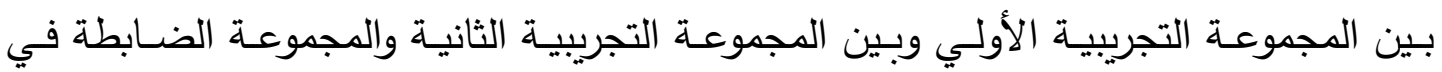
القياس البعدي علي مقياس الدافعية العقلية لصالح المجموعة التدريبية.

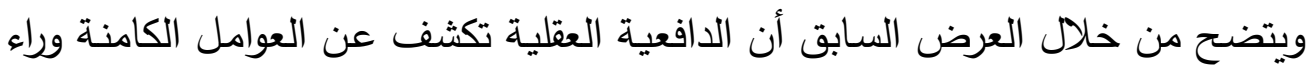
ما يقوم به الطلاب من أنثطة ومهام، هذا إلي جانب إلي أنها تؤهلهم للقيام بأعمال وإنجازات إبداعية جديدة، وتمثل قدرة متميزة علي حل المشكلات بطرق متتوعة ومبتكرة. والدافعية العقلية

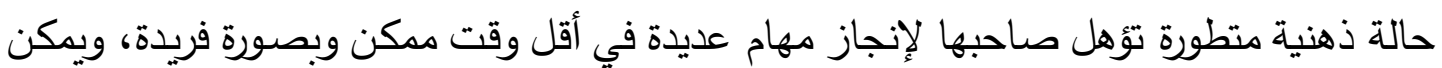
تتميتها لاي الطلاب من خلال البرامج التدريبية.

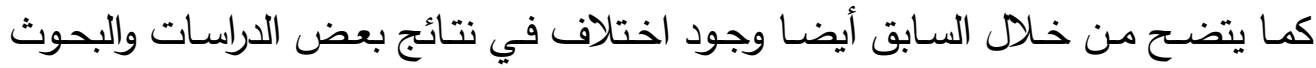
السابقة فيما يتعلق بالفروق بين الذكور والإناث في الدافعية العقلية، فهناك بعض الدراسات والبحوث السابقة التي أشارت إلي عدم وجود فروق في الدافعية العقلية بين الذكور والإناث مثل (أحمد علي، لبعان

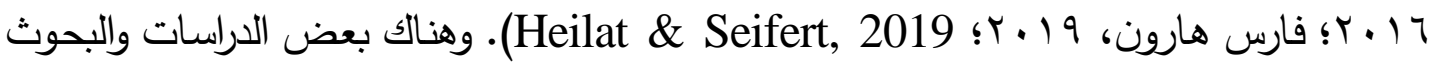
السابقة التي أشارت إلي وجود فروق في الدافعية العقلية بين الذكور والإناث لصالح الإناث مثل باتل (Ylfonso \& Yang, 2019; Martin et al., 2019)

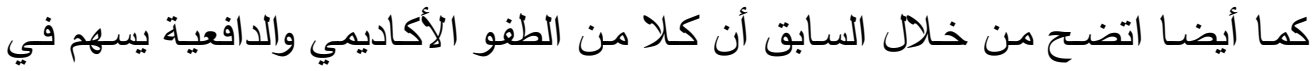
التغلب علي المشكلات والصعوبات الدراسية اليومية، حيث يصبح الطلاب أكثر متعة أثناء

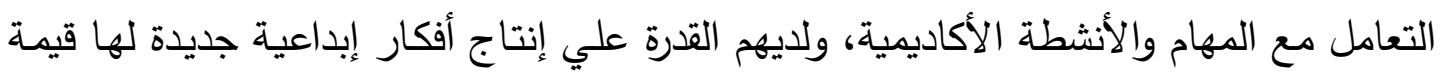

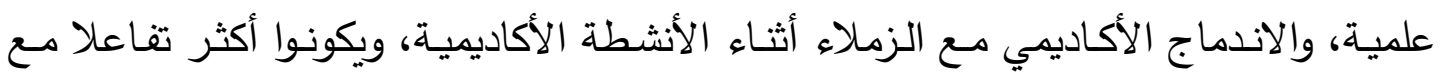

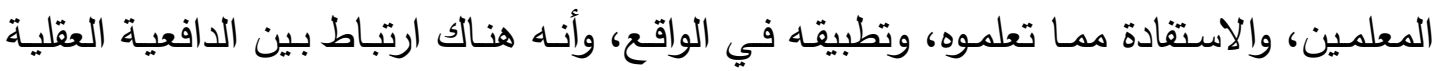
والطفو الأكاديمي، ويتأثر كل منهما بالآخر ويؤثر فيه. 


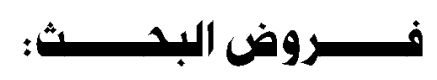

1- توجد علاقة إرتباطية ذات دلالة إحصائية بين الدافعية العقلية والطفو الأكاديمي لدى طلاب الصف الثاني الثانوي. r- لا توجد فروق ذات دلالة إحصائية في الدافعية العقلية بين متوسطي درجات (الذكور الإناث) لدى طلاب الصف الثاني الثانوي. ب- لا توجـد فـروق ذات دلالــة إحصـائية في الطفـو الأكـاديمي بـين متوســي درجـات (الذكور - الإناث) لاثى طلاب الصف الثاني الثانوي. ع- توجد فروق ذات دلالة إحصائية بين متوسطي درجات مرتفعي/ منخفضي الدافعية العقلية في الطفو الأكاديمي لدي طلاب الصف الثاني الثانوي لصالح مرتفعي الدافعية العقلية.

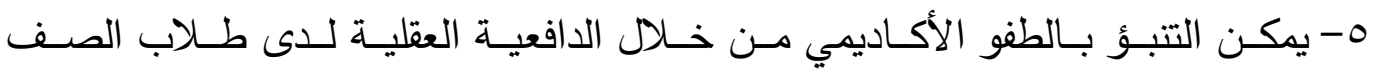
الثاني الثانوي.

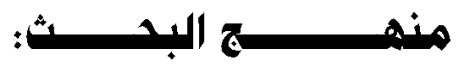

استخدم البحث المنهج الوصفي الذي يتناسب وطبيعة البحث.

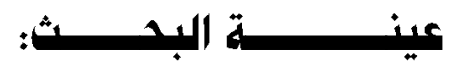

العينة الاستطلاعية ؛

بلغت عينة البحث الاستطلاعية ( • (ه) طالباً وطالبةً من طلاب الصف الثاني الثانوي من مدرسة الفنت الثرقية الثانوية المشتركة بمركز الفشن محافظة بني سويف.

\section{العينــــة الأســاسيــة :}

تكونت عينة البحث الأساسية من ( · . ب) طالباً وطالبةً بالصف الثاني الثانوي بمركز

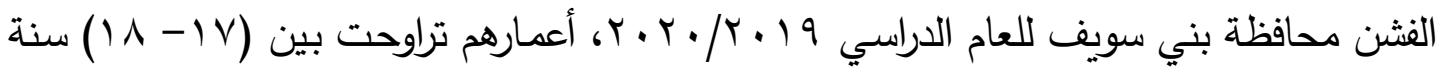

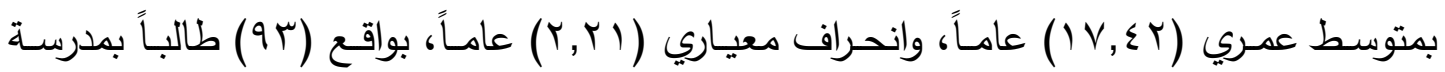
الفشن الثانوية للبنين، و(V • ( ) طالبة بمدرسة الثهيد عصام الدين محمد سالم الثانوية للبنات. 


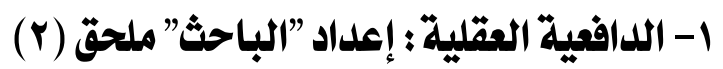

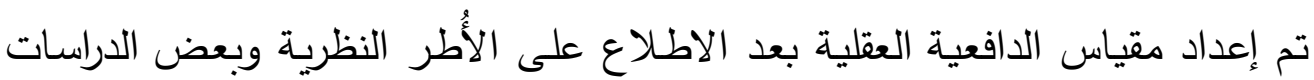

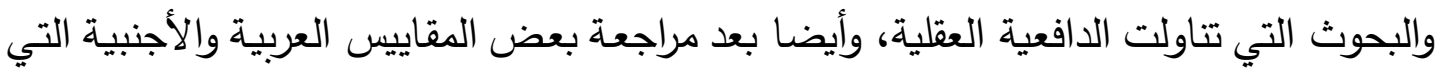
هدفت لقياس الدافعية العقلية ومنها مقياس كاليفورنيا للدافعية العقلية California Measure) of Mental Motivation)

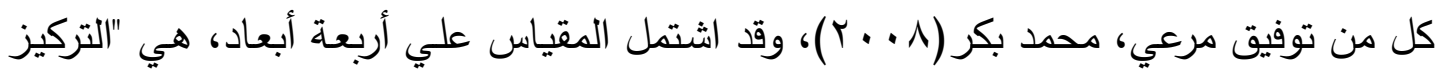

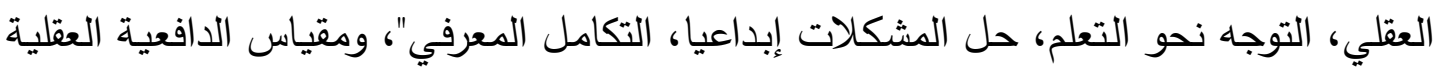

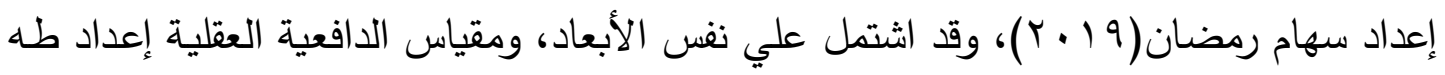

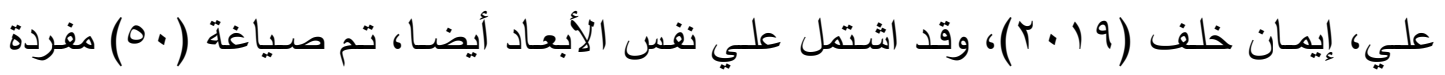
لقياس الدافعية العقلية في صورتها الأولية موزعة علي خمسة أبعاد.

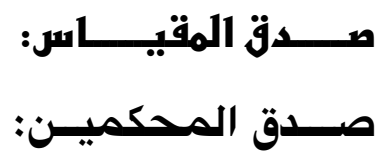

تم عرض المقياس في صورته الأولية على خمسة (0) من المتخصصين في علم

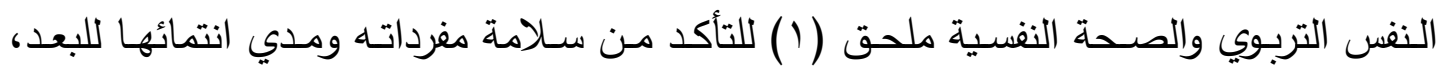

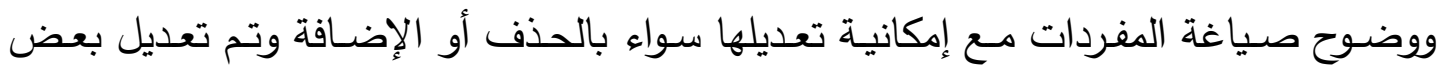

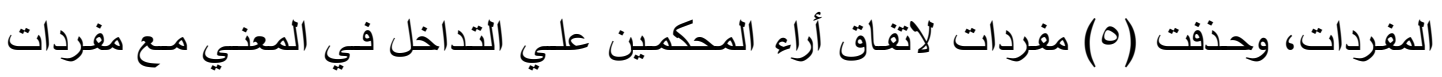

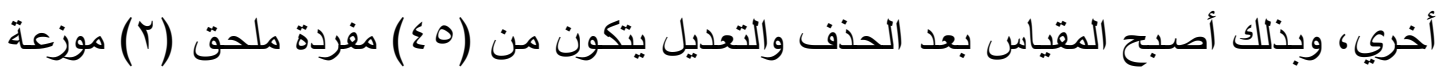
علي خمسة أبعاد هي (التركيز العقلي، التوجه نحو التعلم، حل المشكلات إبداعيا، التكامل المعرفي، الفضول والانفتاح العقلي) بواقع (9) مفردات لكل بُعد من أبعاد المقياس.

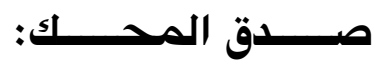

تم التحقق من صدق المحك بحساب صدق المقياس في البحث الحالي عن طريق

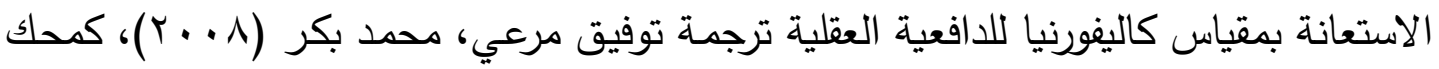

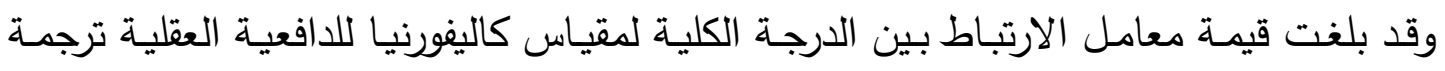

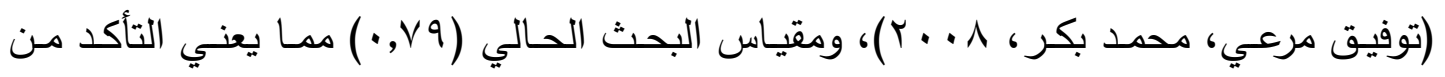
صدق المقياس ومناسبته للبحث الحالي. 


\section{الصـدق العــاملــيـي:}

تم استخدام الصدق العـاملي باستخدام طريقـة المكونـات الأساسية، وتدوير الدحاور

بطريقة الفاريماكس Varimax Rotation، واستخدام محك "كايزر" لاستبقاء المفردات ذات

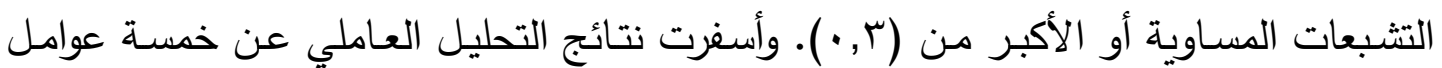

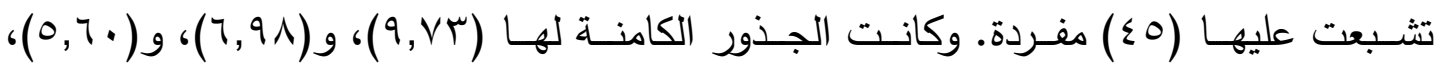

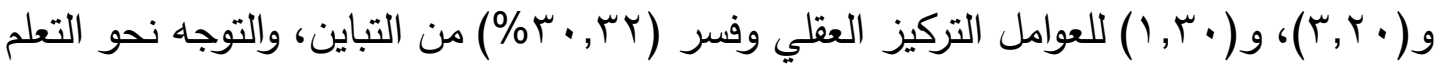

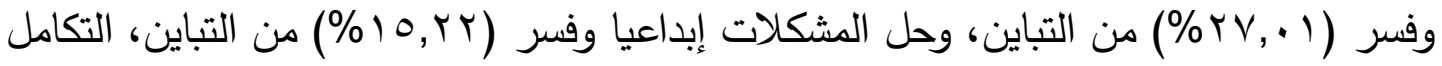

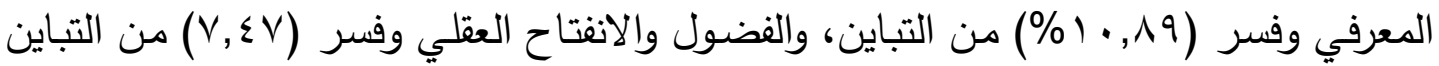

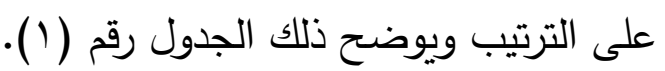
جدول (1) تشبعات مفردات مقياس الدافية الققلية بعد التدوير

\begin{tabular}{|c|c|c|c|c|c|c|c|c|c|}
\hline | الفضول والانفتاح & رقمر & التكامل & رقمث & حل المشكلات & رقهم & التوجه نحو & رقمر & العقليز & رقم المفردة \\
\hline$\cdot$, ¿ & $r$ & •, Or & 7 & $\cdot, \mathrm{HA}$ & $r$ & $\bullet,\{7$ & $\xi$ & $\bullet, \$ 1$ & 1 \\
\hline$\cdot$, ¿ह & 19 & $\cdot, 09$ & 1. & $\cdot, 01$ & $\Lambda$ & $\cdot, 0\}$ & 11 & $\cdot, 07$ & 0 \\
\hline$\cdot$, ¿\& & YI & $\cdot, 71$ & ir & $\cdot, 09$ & 9 & $\cdot, 89$ & 10 & $\cdot,\{V$ & $v$ \\
\hline$\cdot$, \£ & Yz & $\cdot, 7 \varepsilon$ & IV & $\cdot, \mathrm{Ar}$ & ir & •, §0 & $M$ & $\cdot, \leqslant 9$ & 17 \\
\hline$\cdot, \llbracket \leftleftarrows$ & ro & $\cdot$, \&1 & rr & $\cdot, 70$ & $1 \varepsilon$ & $\cdot$, \£ & rq & $\cdot, 7$ & rr \\
\hline$\cdot, v$. & r. & •,OV & rq & $\cdot, 09$ & r. & $\cdot, \$ 7$ & rr & $\cdot, 7 r$ & rV \\
\hline$\cdot,\{r$ & rr & $\cdot,\{9$ & rs & $\cdot, 70$ & rA & $\cdot, 0 \wedge$ & ro & $\cdot, \xi r$ & rI \\
\hline$\bullet, 7$. & rq & $\cdot, r q$ & $\sum r$ & •, Or & rV & $\cdot, 01$ & rq & $\cdot, 7$ & rA \\
\hline$\cdot, 0 \Lambda$ & ¿r & •, Ir & $\{\xi$ & $\cdot, 77$ & $\leqslant 0$ & $\cdot, 09$ & $\$ 1$ & $\cdot, 70$ & $\xi$ \\
\hline I,r. & & $r, r$. & & 0,7 . & & 7,91 & & $9, V r$ & الجذر الكامن \\
\hline$v, v \varepsilon$ & & $1 \cdot, \wedge \Lambda$ & & $10, Y 1$ & & $r V, \cdot r$ & & $r \cdot, r r$ & التباين المفسر \\
\hline
\end{tabular}

\section{الاتســــاق الــــداخلـــــي}

تم التحقق من الاتساق الداخلي للمقياس وكل بعد من أبعاده، ويوضح ذلك الجدول

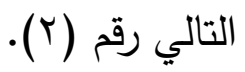

جلدول (r) معاملات الارتباط بين أبعاد مقياس الدافية العقلية والدرجة الكلية للمقياس

\begin{tabular}{|c|c|}
\hline معامل الارتباط بالدرجة الكلية & أبعاد الدافية العقلية \\
\hline$*_{*}^{*}, \mathrm{Al}$ & التركيز العقلي \\
\hline$* *, A T$ & التوجه نحو التعله \\
\hline$*_{*}^{*}, \lambda_{\bullet}$ & حل الشكلات إبداعيا \\
\hline$* *, \mathrm{vq}$ & التكامل المعرفي \\
\hline${ }^{* *}, \mathrm{Al}$ & الفضول والانفتاح العقلي \\
\hline
\end{tabular}


يتضـح مـن الجدول (Y) أن معـاملات الارتبـاط جـاءت مرتفعـة ويـدل ذلك على قوة

التماسك الداخلي للمقياس، وكذلك في كل بعد من أبعاده، ولذا يعتبر المقياس مناسبا للاستخدام

$$
\text { في البحث الحالي. }
$$

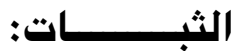

تم التحقق من ثبات المقياس باستخدام طريقة "ألفا كرونباخ" لتقدير ثبات المقياس، بعد

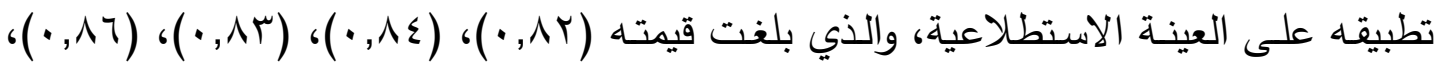
( ( •, • للأبعاد: (التركيز العقلي، التوجه نحو التعلم، حل المشكلات إبداعيا، التكامل المعرفي، الفضول والانفتاح العقلي) على الترتيب، وهي قيم مرتفعة ويمكن الاعتماد عليها. تصصيــح المقب.بـا1سر:

تكون المقياس بصورته النهائية من (0ء) مفردة، تتم الإجابة عليه وفق تدريج ليكرت خماسي التقدير "تطبق علي تماما، تطبق علي كثيرا، تطبق علي أحيانا، تتطبق علي نادرا، لا نطبق علي

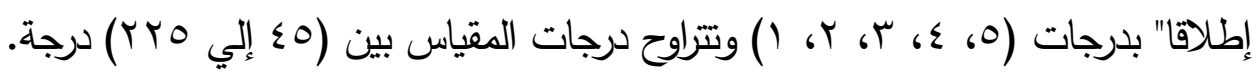

(Piosang, بcademic Buoyancy Scale إعداد الطفو الاكاديمي 2016)

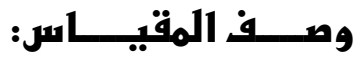

قام بوسنج Piosang بإعداد مقياس الطفو الأكاديمي والذي تألف من ( • (०) مفردة موزعـة علـي خمسـة أبعـاد هـي (الفاعليـة الذاتيـة، السـيطرة غيـر المؤكـدة، القلـق، الانــدماج الأكاديمي، العلاقة بين المعلم والطالب). وقد استخدمت دراسات وبحوث سابقة مقياس الطفو (Collie, et al., 2016; Collie, et al., 2017; منها (Piosang, 2016) الأكاديمي لـ .Anderson, 2019; Safoura \& Behzad, 2019) قـام معد المقياس بحسـاب صـدق المقياس باستخدام التحليل العـاملي والإبقـاء على العبارات التي تثبعت بصورة دالة، على عينة تكونت من ( • r طالباً، كما تم حساب الفروق بين الطلاب مرتفعي ومنخفض التحصيل في الأداء على المقياس وكانت دالة، كما وجدت فروق دالة بين طلاب الفرقة الأولي وطلاب الفرقة الرابعة. وبلغت قيمـة معامل الثبات بطريقة 
"ألفـا كرونبـاخ" للبعد الأول (الفاعليـة الذاتيـة) (V0, • )، وللبعد الثاني (السيطرة غير المؤكدة)

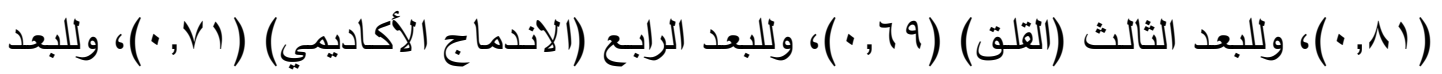
الخامس (العلاقة بين المعلم والطالب) ( ع > • )، وهي قيم مرتفعة (Piosang, 2016).

\section{الصدق والثبات في المورة المعربةة:}

تم ترجمة المقياس من اللغة الانجليزية إلى اللغة العربية، وعرضهه على ثلاثة متخصصين باللغة الانجليزية للتأكد من صحة الترجمة، كما تم إجراء ترجمة عكسية للمقياس من اللغة العربية إلى اللغـة الإنجليزيـة من مختص آخر في اللغة الإنجليزيـة، وذلك للتأكد من محافظة كل مفردة على معناها الأصلي في المقياس وتم إجراء تعديلات طفيفة على النص العربي لبعض الفقرات.

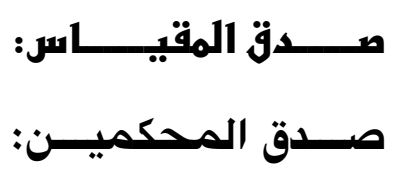

تم عرض المقياس في صورته الأولية على خمسة (0) من المتخصصين في علم النفس التربوي والصحة النفسية ملحق (1) للتأكد من سـلامة مفرداته ومدي انتمائها للبعد، ووضوح صياغة المفردات مع إمكانية تعديلها سواء بالحذف أو الإضـافة، وقد أجمع المحكمون على أن الفقرات تنتمي إلى المقياس المكون من ( •(0) مفردة ملحق (ب) موزعة علي خمسة أبعاد هي (الفاعليـة الذاتيـة، السـيطرة غيـر المؤكدة، القلق، الانـدماج الأكـاديمي، العلاقـة بـين المعلـم والطالب)، بواقع ( • () مفردات لكل بُعد من أبعاد المقياس. صـدق المحــــ

تم التحقق من صدق المحك بحسـاب صدق المقياس في البحث الحالي عن طريق الاستعانة بمقياس الطفو الأكاديمي إعداد حسن سعد (1 ( • ب)، كمحك وقد بلغت قيمة معامل

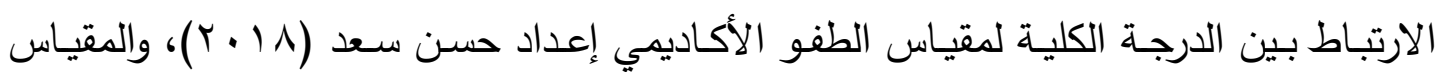
الحالي (VT, • • ) مما يعني التأكد من صدق المقياس ومناسبته للبحث الحالي. الاتشسـاق الـــداخلــي تم التحقق من الاتسـاق الداخلي للمقياس وكل بعد من أبعاده، ويوضـح ذلك الجدول

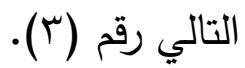


جلول (r) معاملات الارتباط بين أبعاد مقياس الطفو الاكاديمي والدرجة الكلية للمقياس

\begin{tabular}{|c|c|}
\hline معامل الارتباط بالدرجة الكلية & أبعاد الطفو الاكاديمي \\
\hline$* *, \vee \vee q$ & الفاعلية الذاتية \\
\hline$* *, \Lambda$ & السيطرة غير المؤكلة \\
\hline$* *,, \vee 0$ & القلق \\
\hline$* *, V Y$ & الاندماج الاكاديمي \\
\hline$* *, \vee \vee A$ & العلاقة بين المعلم والطالب \\
\hline
\end{tabular}

يتضـح مـن الجدول (r) أن معساملات الارتبـاط جـاءت مرتفعـة ويـدل ذلك على قـوة

التماسك الداخلي للمقياس، وكذلك في كل بعد من أبعاده، ولذا يعتبر المقياس مناسبا للاستخدام

$$
\text { في البحث الحالي. }
$$

تم التحقق من ثبات المقياس باستخدام طريقة "ألفا كرونباخ" لتقدير ثبات المقياس، بعد

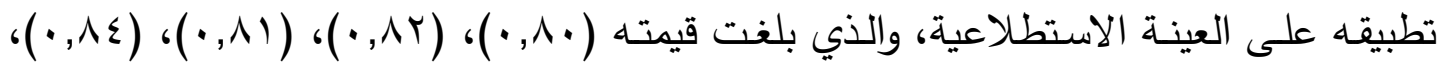
( • (^, • للأبعاد (الفاعلية الذاتية، السيطرة غير المؤكدة، القلق، الاندماج الأكاديمي، العلاقة بين المعلم والطالب)، على الترتيب، وهي قيم مرتقعة ويمكن الاعتماد عليها. تصمبـــح المقبيـــاسر:

تكون المقياس بصورته النهائية من ( •0) مفردة، تتم الإجابة عليه وفق تدريج ليكرت

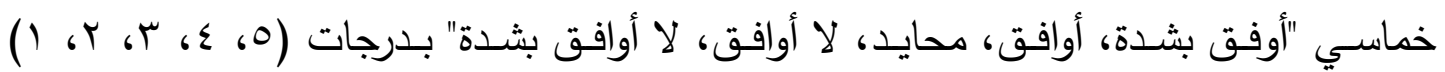

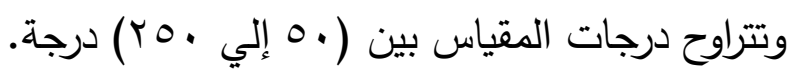

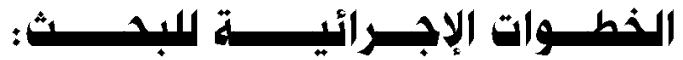

للإجابة عن أسئلة البحث تم المرور بالخطوات التالية:

• جمع الأدبيات المرتبطة بموضوع البحث من إطار نظري ودراسات وبحوث سابقة. التأكد من صدق وثبات الأدوات المستخدمة في البحث الحالي وهى مقياس الدافعيـة العقلية، ومقياس الطفو الأكاديمي على العينة الاستطلاعية. تطبيق مقياس الدافعية العقلية على العينة الأساسية. تطبيق مقياس الطفو الأكاديمي على العينة الأساسية. جمع وتبويب بيانات البحث ومعالجتها إحصائياً للإجابة عن تساؤلات البحث والتحقق الادئ من فروضنه. مناقشة وتقسير النتائج وتقديم التوصيات والبحوث المقترحة والتي ترتبط بنتائج البحث. 


\section{الأســـاليـــب الإحصـــائيــــة :}

تم استخدام اختبار "ت" للعينـات غير المرتبطـة وتحليل الاتحدار المتعدد التدريجي ومعامل الارتباط لبيرسون، وتمت جميع المعالجات الإحصائية باستخدام البرنامج الإحصائي

.SPSS (V22)

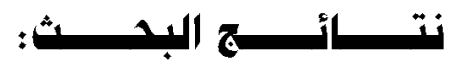

يمكن تناول نتائج البحث من خلال التالي:

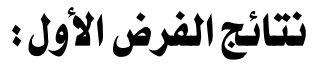

للتحقق من الفرص الأول: والذي ينص علي أنه توجد علاقة إرتباطية ذات دلالة إحصائية

بين الدافعية العقلية والطفو الأكاديمي للى طـلاب الصف الثاني الثانوي. تم حسـاب معاملات

الارتباط بيرسون بين الدافعية العقلية والطفو الأكاديمي وكانت النتائج كما في الجدول رقم (ع).

\begin{tabular}{|c|c|c|c|c|c|}
\hline |العلاقة بين المعلد والطالب & |الاندماج الاكاديمي & القلق & السيطرة غير المؤكلة & | الفاعلية الذاتية & البعـــــــــــل \\
\hline$*, 10\}$ & **, rar & $* *_{\bullet}, \boldsymbol{Z} \cdot r-$ & $* *$, ryo- & **, हैrr & التركيز العقلي \\
\hline$* *, r \cdot \Lambda$ & $* *_{\bullet}, r \leqslant r$ & $* *$, HIQ- & $* *, r \wedge r-$ & $* *, r q \Lambda$ & التوجه نحو التعلم \\
\hline$* * \bullet, \leq \leqslant 7$ & $* *,\{7\rceil$ & $*_{\bullet}, 1 \leqslant 0-$ & $* * \cdot, r \cdot r-$ & $* *, 0 \leqslant r$ & حل المشكلات إبلاعيا \\
\hline$*_{*}^{*}, \gtrless 1$ & $*_{\bullet,}^{*}(1)$ & $*, 170-$ & $* * \cdot, r \Lambda \cdot-$ & $* *,, \preceq 07$ & التكامل المعرفي \\
\hline$*, 111$ & $* *,, 7 \vee 1$ & $* *$, rOA- & $* * \bullet,\{\cdot 1-$ & $*, 011$ & الفضول والانفتاح العقلي \\
\hline$* *$, or. & $* *_{\bullet,}, \$ 9 \Lambda$ & $* *_{\bullet,\{0 \wedge-}$ & $* *_{\bullet}, 011-$ & $* * \bullet$, orl & |اليقظة العقلية \\
\hline
\end{tabular}

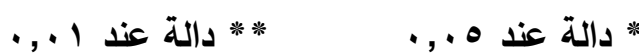

اتضـح من الجدول رقم (ع) وجود علاقة إرتباطية موجبة دالة إحصائياً بين الدافعية

العقلية والدرجة الكلية وبين أبعاد الطفو الأكاديمي (الفاعلية الذاتية، الاندماج الأكاديمي، العلاقة

بين المعلم والطالب) لدي طلاب الصف الثاني الثانوي، ووجود علاقة إرتباطية سالبة دالـة إحصائياً بين الدافعية العقلية والدرجة الكلية وبين أبعاد الطفو الأكاديمي (السيطرة غير المؤكدة، القلق)، وبالتالي تحقق الفرض الأول. 
للتحقق مـن صـحة الفرض الثاني: والذي ينص علي أنسه لا توجد فروق ذات دلالـة إحصائية في الدافعية العقلية بين متوسطي درجات (الذكور - الإناث) لدى طلاب الصف الثاني الثانوي. تم استخدام اختبار "ت" لحساب قيمة ودلالة الفروق بين المتوسطات غير المرتبطة، ويوضح الجدول رقم (0) نتائج ذلك.

جلول (0) نتائج اختبار "ث” لدلالة الفروق بين ( الذكور - الإناث) في الدافية العقلية

\begin{tabular}{|c|c|c|c|c|c|}
\hline قيمة"ت” & الانحراف المعياري & المتوسط & ن & النوع & البعــــــــد \\
\hline \multirow{2}{*}{$\cdot, 101$} & $0, \cdot \cdot$ & $r o,\{7$ & 94 & ذكور & \multirow{2}{*}{ التركيز العقلي } \\
\hline & $\{, \wedge 01$ & $r 0,07$ & $1 \cdot v$ & إناث & \\
\hline \multirow{2}{*}{$\cdot,\{91$} & $r, r \leqslant 1$ & II,Ar & 94 & ذكور & \multirow{2}{*}{ التوجه نحو التعلد } \\
\hline & $r, 7 T H$ & $11,7 r$ & $1 \cdot v$ & إناث & \\
\hline \multirow{2}{*}{ •, rrr } & r,rr & $10,7 r$ & 94 & ذكور & \multirow{2}{*}{ حل المشكلات إبلاعيا } \\
\hline & $r, \xi V r$ & $10, v 7$ & $1 \cdot v$ & إناث & \\
\hline \multirow{2}{*}{$\cdot, r 90$} & r,YII & 11,19 & ar & ذكور & \multirow{2}{*}{ التكامل المعرفي } \\
\hline & 1,914 & $11,\{r$ & $1 \cdot v$ & إناث & \\
\hline \multirow{2}{*}{ •, rs } & r,YrI & $10,0 \mathrm{r}$ & 94 & ذكور & \multirow{2}{*}{ الفضول والانفتاح العقلي } \\
\hline & r,rir & $1 \xi$ or & $1 \cdot v$ & إناث & \\
\hline \multirow{2}{*}{ •, rAr } & $\Lambda, Y M$ & $9 \cdot, 7 v$ & ar & ذكور & \multirow{2}{*}{ الدرجة الكلية } \\
\hline & ro,rq & $\wedge 9,71$ & $1 \cdot r$ & إناث & \\
\hline
\end{tabular}

يتضح من الجدول رقم (0) عدم وجود فروق ذات دلالة إحصائية بين متوسطي درجات الطلاب (الذكور - الإناث) في أبعاد الدافعية العقلية وبذلك تحقق الفرض الثاني.

\section{نتائج الفرض الثالث}

للتحقق من الفرض الثالث: والذي ينص علي أنه لا توجد فروق ذات دلالة إحصائية في الطفو الأكـاديمي بـين متوسطي درجـات (الذكور - الإنـاث) لـى طـلاب الصـف الثاني الثانوي. تم استخدام اختبار "ت" لاتلالة الفروق بين المتوسطات غير المرتبطة، ويوضـح الجدول رقم (ך) نتائج ذلك. 
جلول ( ) نتائج اختبار ”ت” للدلالة الفروق بيز ( الذكور - الإناث) في الطفو الاكاديمي

\begin{tabular}{|c|c|c|c|c|c|}
\hline قيمة ”ت"ومستوي دلالتها & الانحراف المعياري & المتوسط & j & النوع النوع & البعـــــــد \\
\hline \multirow{2}{*}{$*$ * } & $r, Y A I$ & 19,01 & ar & ذكور & \multirow{2}{*}{ الفاعلية الذاتية } \\
\hline & $r,|r|$ & $r \cdot, o r$ & $1 \cdot v$ & إناث & \\
\hline \multirow{2}{*}{ •, बrr } & r,ATr & rI, rr & ar & ذكور & \multirow{2}{*}{ السيطرة غير المؤكدة } \\
\hline & $r, v Y I$ & MI,Hr & $1 \cdot V$ & إناث & \\
\hline \multirow{2}{*}{ 1,Zrr } & r,§rr & 19,19 & $9 r$ & ذكور & \multirow{2}{*}{ القلق } \\
\hline & $\xi, 1 \xi r$ & $19,1 r$ & $1 \cdot v$ & إناث & \\
\hline \multirow{2}{*}{$* * \Psi, \wedge Y I$} & $r, \bullet \wedge$ & $\mid 1,11$ & ar & ذكور & \multirow{2}{*}{ الاندماج الاكاديمي } \\
\hline & r,\&Hr & 19,74 & $1 \cdot V$ & إناث & \\
\hline \multirow{2}{*}{$* * Y, 00 Y$} & r, rrr & $1 \xi, \mid r$ & 94 & ذكور & \multirow{2}{*}{ العلاقة بين المعلم والطالب } \\
\hline & 1,778 & $10,1 \%$ & $1 \cdot v$ & إناث & \\
\hline \multirow{2}{*}{ **Y,YAY } & $v,|\xi|$ & $9 r, 90$ & ar & ذكور & \multirow{2}{*}{ الدرجة الكلية } \\
\hline & \&, ror & $90, \mathrm{Vr}$ & $1 \cdot v$ & إناث & \\
\hline
\end{tabular}

اتضـح من الجدول رقم (7) وجود فروق ذات دلالة إحصائية بين متوسطي درجات الطلاب (الذكور - الإناث) في أبعاد الطفو الأكاديمي (الفاعلية الذاتية، الاندماج الأكاديمي، العلاقة بين المعلـم والطالب، الدرجـة الكليـة) لصـالح الإنـاث، وعدم وجـود فـروق في بقيـة أبعـاد الطفو الأكاديمي (السيطرة غير المؤكدة، القلق) وبذلك تحقق الفرض الثالث جزئيا.

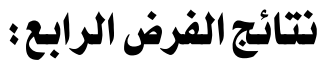

للتحقق من صحة الفرض الرابع: والذي ينص علي أنه توجد فروق ذات دلالة إحصائية بين متوسطي درجات مرتفعي(') ومنخفضـي(r) الدافعيـة العقلية في الطفو الأكاديمي لصـالح مرتفعي الدافعيـة العقليـة. تم ترتيب طـلاب عينـة البحث تنازليـا وفق الدرجـة الكليـة للدافعيـة العقلية، ثم حساب كل من الإرباعي الأول والثالث، ثم اختيار الطلاب الحاصلين علي درجات أعلي من قيمة الإرباعي ليمثلوا مرتفعي الدافعية العقلية، والطلاب الحاصلين علي درجات أقل من الإرباعي الأول ليمثلوا منخفضي الدافعية العقلية، ثم تم استخدم اختبار "ت" لدلالة الفروق

(1) مرتفعي الدافعية العقلية الذين حصلوا على درجة ؟1 ا فأكثر (الارباعي الأعلى) في مقياس الدافعية العقلية. (Y) منخفضي الدافعية العقلية الذين حصلوا على درجة (ب فأقل (الإباعي الأدنى) في مقياس الدافعية العقلية. 
بين متوسطات درجـات الطـلاب مرتفعي ومنخفضـي الدافعيـة العقليـة في الطفو الأكـاديمي، والجدول رقم (V) يبين نتائج ذلك.

جدول (v) نتائج اختبار ”ت" لدلالة الفروق بين متوسطي درجات مرتفعي ومنخفضي الأداء على الدافية العقلية في الطفو الاكاديمي

\begin{tabular}{|c|c|c|c|c|c|}
\hline قيمة "ت" ومستوي دلالتها & الانحراف المعياري & المتوسط & $\dot{j}$ & المجموعة & 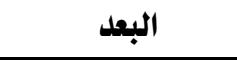 \\
\hline \multirow{2}{*}{$* * \wedge, \vee \backslash 1}$. & $9,9 r$ & $\{v, \bullet \xi$ & or & منخفض & \multirow{2}{*}{ الفاعلية الذاتية } \\
\hline & 7,71 & $\eta \cdot$, Ar & or & مرتفع & \\
\hline \multirow{2}{*}{$* * \wedge, \cdot 91$} & $9,0 \gamma$ & or,or & or & منخفض & \multirow{2}{*}{ السيطرة غير المؤكلة } \\
\hline & $v, r \wedge$ & $\{Y, 01$ & ov & مرتقع & \\
\hline \multirow{2}{*}{$* * \vee, 771$} & $\wedge, \Delta \wedge$ & Or,Ar & or & منخفض & \multirow{2}{*}{ القلق } \\
\hline & $7,7 r$ & $\{\Lambda, 7 r$ & or & مرتقع & \\
\hline \multirow{2}{*}{$* * V, 19 Y$} & 0,9 . & $r \varepsilon, r q$ & or & 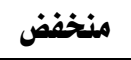 & \multirow{2}{*}{ الاندماج الاكاديمي } \\
\hline & $\xi, \xi Y$ & $\$ 1, r v$ & or & مرتفع & \\
\hline \multirow{2}{*}{$* * V, Y Y Y$} & Ir, & $7 \varepsilon, 90$ & or & منخفض & \multirow{2}{*}{ العلاقة بين المعلى } \\
\hline & $1 \cdot, 0$ & $\wedge 1, \ 0$ & or & مرتقع & \\
\hline \multirow{2}{*}{${ }^{* *}$ A, व व } & एะ, \&। & PrI,O. & or & منخفض & \multirow{2}{*}{ اللدرجة الكلية } \\
\hline & Yo, $\$ 9$ & $r \cdot q, Y q$ & 70 & مرتفع & \\
\hline
\end{tabular}

** دالة عند مستوى دلالة ا ., ...

اتضح من الجدول (V) وجود فروق ذات دلالة إحصائية بين متوسطي درجات مرتفعي ومنخفضـي الأداء علـي مقيـاس الدافعيـة العقليـة في الطفـو الأكـاديمي، علـي أبعـاد الطفـو الأكاديمي (الفاعليـة الذاتيـة، الاندماج الأكاديمي، العلاقـة بين المعلم والطالب، الدرجـة الكليـة) لصـالح مرتفعي الدافعيـة العقليـة ، ووجـود فروق في أبعـاد الطفو الأكـاديمي (السيطرة غيـر المؤكدة، القلق) لصالح منخفضي الدافعية العقلية.

\section{نتائج الفرض الخامس}

للتحقق من صحة الفرض الخامس: والذي ينص علي أنه يمكن التنبؤ بالطفو الأكاديمي مـن خـلال الدافعيـة العقليـة لدى طـلاب الصـف الثاني الثانوي. تـم استخدام تحليـل الانحـدار المتعدد التدريجي على النحو التالي: 
جدول ( 1) نتائج تحليل الانحلار المتعدد التدريجي حسب أهمية تأثير العوامل المستقلة (الدافية العقلية) على المتفير التابع ( الطفو الاكاديمي)

\begin{tabular}{|c|c|c|c|c|c|c|c|}
\hline ”" ومستوى دلالتها & "ف" ومستوى دلالتها & Beta & B & التفير في R2 & $\mathbf{R 2}$ & $\mathbf{R}$ & أبعاد الدافيية العقلية \\
\hline$* * \eta, Y Y Y$ & $* *\{0,17 \Lambda$ & - IAT & , ror & $\cdot$, IAv & - IAv & 佂 & التركيز العقلي \\
\hline$* * 0,7 \leqslant 9$ & $* * \psi 1, q . r$ & - & , r. II & 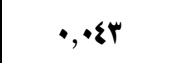 & $\cdot, 1 \xi$. & $\cdot, r v \varepsilon$ & حل المشكلات إبداعيا \\
\hline$* * \xi, \xi V r$ & $* * Y, \Lambda \cdot r$ & $\cdot, 01$ & $\cdot, \cdot 17 r$ & $\cdot, 11 \varepsilon$ & •, & • 174 & الفضول والانفتاح العقلي \\
\hline
\end{tabular}

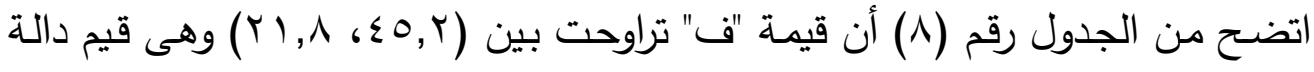
عند مستوى (1 ·, •)، وهذا يشير إلى فاعلية الدافعية العقلية في التنبؤ بالطفو الأكاديمي لأي

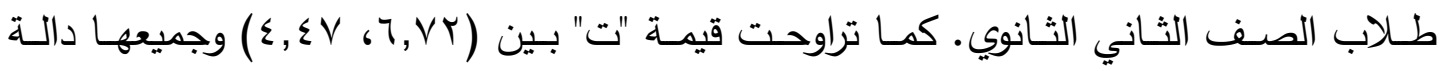
إحصـائيا عند مستوى (1 ., ·). وذلك يدل على تحقق الفرض الرابع جزئيا، كما يتضـح من الجـدول رقـم (^) أن أهـم العوامـل المسـتقلة للدافعيـة العقليـة والتـي تسـهم في التتبؤ بـالطفو

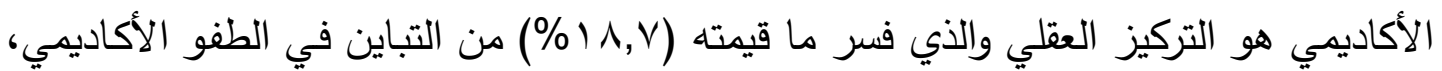
يليه الفضول والانفتاح العقلي والذي فسر ما قيمته (ع, (1\%) من التباين في الطفو الأكاديمي، يليه حل المشكلات إبداعيا والذي فسر ما قيمته (ץ,؟\%) من التباين في الطفو الأكاديمي. كما يمكن صياغة معادلة التنبؤ بالطفو الأكاديمي من أبعاد الدافعية العقلية كالتالي:

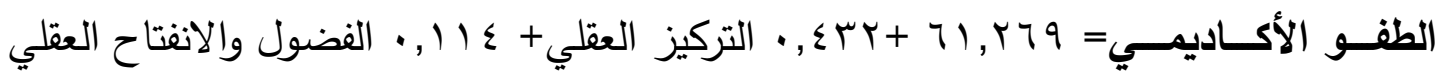
( إبداعيا.

أما بالنسبة لمدى مساهمة أبعاد الدافعية العقلية (التركيز العقلي، حل المشكلات إبداعيا) مجتمعة ومنفردة في تفسير التباين في درجات الطلاب في الطفو الأكاديمي، فقد بينت نتائج الانحدار المتعدد أن نسبة ما تفسره تلك الأبعاد مجتمعة قد بلغ ، ع, ه9\% وهذا يشير إلى أن تلك الأبعاد الثثلثة فسرت نسبة عالية من التباين في الطفو الأكاديمي في حين أن النسبة الباقية تفسرها عوامل أخرى. 


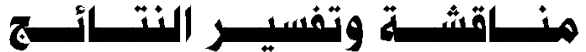

أشارت نتائج الفرض الأول إلي وجود علاقة إرتباطية إيجابية دالة إحصائياً بين الدافعية

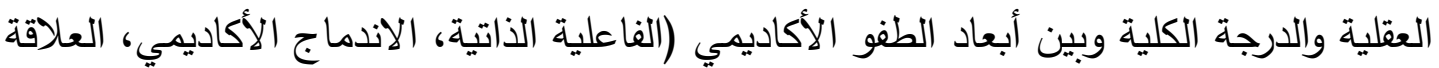

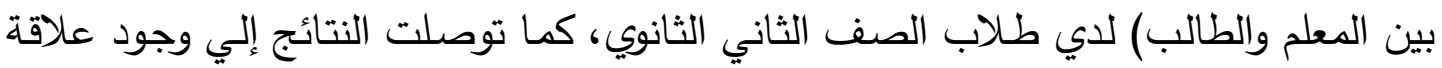
إرتباطية سلبية دالة إحصائياً بين الدافعية العقلية وبين أبعاد الطفو الأكاديمي (السيطرة غير لوكائ المؤكدة، القلق)، وبالتالي تحقق الفرض الأول.

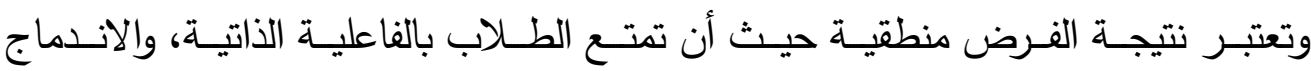

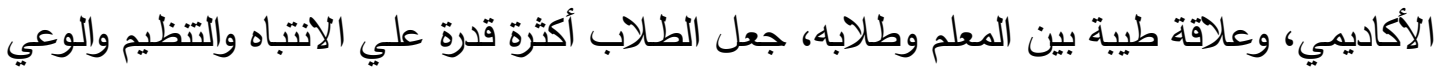

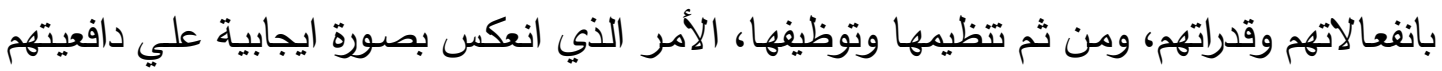

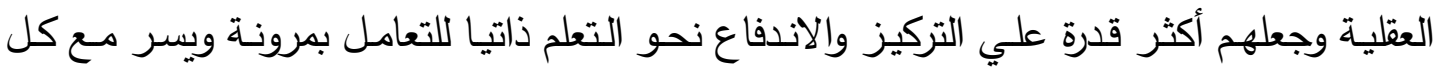

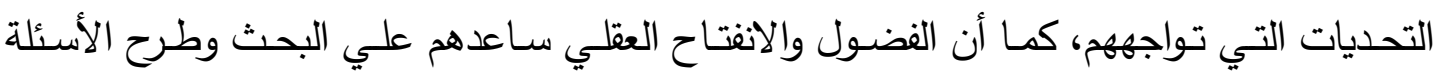

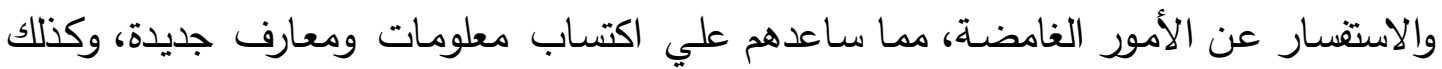
اكتساب القدرة على التحدي ومواجهة المشكلات الصعبة، والثعور بالرضا عند حلها، واستخدام مهارات تفكير موضوعية تجاه جميع الأفكار، والوصول إلي حلول إبداعية ومتتوعة للمشكلات. كما أشـار (2019) Alfonso \& Yang إلي أن الطلاب ذو الدافعية العقلية المرتفعة يتسمون بطفو أكاديمي مرتفع، وبالتالي يتمتعون بصحة نفسية وجسمية، ويتميزون بانفعالاتهم الايجابية، ويحظون بعلاقات اجتماعية مستقرة وطيبة، كما تعد الدافعية العقلية والطفو الأكاديمي عاملان حاسمان في عملية التعلم، فعندما يتميز الطلاب بالدافعية العقلية

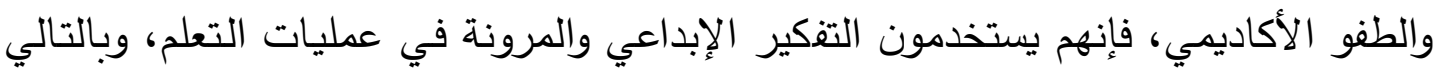

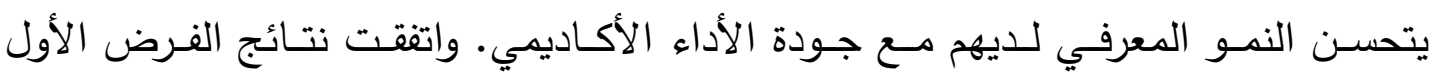
ونتائج(Smith, 2016; Omaima, 2018; Alfonso \& Yang, 2019). كما يمكن تفسير نتيجة الفرض الأول بأن اندماج الطلاب في مناقثات فردية وجماعية

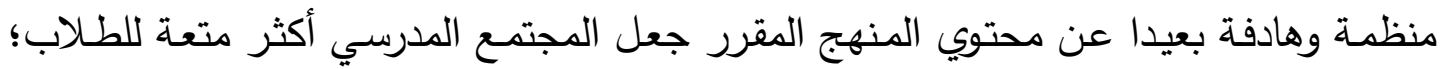

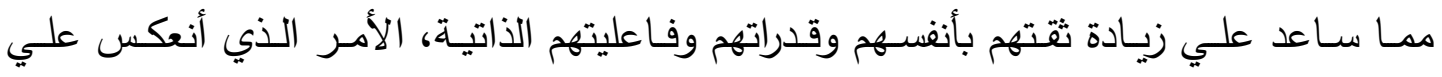

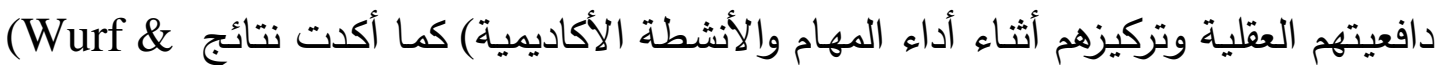

.Groft-piggin, 2015; Martin et al., 2019) 
أشـارت نتائج الفرض الثاني إلي أنـه لا توجد فروق ذات دلالة إحصـائية في الدافعيـة العقلية بين متوسطي درجات (الذكور - الإنـاث) لدى طـلاب الصف الثاني الثانوي. ويمكن تفسير تلك النتيجـة في ضـوء أن كل مـن الذكور والإنـاث يعيشـون نفس المرحلـة العمريـة، ويتعرضون لنفس المتطلبات التعليمية، ويقع عليهم نفس الأعباء الدراسية، وهذا يتطلب منهم قدر مناسب من الانتباه والتركيز العقلي والإقبال علي الأنشطة التعليمية بصدر رحب، ومرونـة في التعامل مـع المشكلات والتحديات الأكاديمية، كما أن أعباء الأنشطة التعليمية تتطلب من الذكور والإنـاث التركيز والوعي في عملية التعلم، مما يجعلهم علي نفس القدر مـ البحث والإطلاع والاستكثـاف والانفتاح علي كل مـا هو جديد؛ لتلبية متطلباتهم التعليمية، وتحقيق إنجازات في حياتهم الشخصية والأكاديمية والاجتماعية. واتفقت نتائج الفرض الثاني ونتائج (Heilat \& Seifert, 2019) والتي توصلت إلي عدم وجود فروق في الدافعية العقلية بين الذكور والإناث. وكذلك نتائج (أحمد علي، 7 أ بـ؛ فارس هـارون، 9 ( • ب) والتي توصلت إلي عدم وجود فروق في الدافعية العقلية بين الذكور Alfonso \& Yang, 2019; Martin et ) والإناث. واختلفت نتيجة الفرض الثاني ونتائج al., 2019 طـه علي، إيمان خلف، 9 ( • ب) والتي توصلت إلي وجود فروق في الدافعيـة العقلية بين الذكور والإناث لصـالح الإناث. كما تتفق نتائج الفرض الحالي جزئيا ونتائج بحث محمد علي (T ( • Y) والتي توصـلت إلي عدم وجود فروق في الدافعيـة العقليـة بين الذكور والإناث، فيما عدا بُعد التركيز العقلي والذي أشارت النتائج إلي وجود فروق بين الذكور والإناث لصـالح الإنـاث في التركيز العقلي، حيث أن الطالب الذي لديـه ضـف في التهي التركيز العقلي أتصف بقدرة منخفضة في تركيز وتتظيم انتباهه، والميل إلي عدم التظيم والتسويف الأكاديمي، وتكَكون لديه شعور بالإحباط أثناء مواجهة للمشكلات. أشارت نتائج الفرض الثالث إلي وجود فروق ذات دلالة إحصائية بين متوسطي درجات الطلاب (الذكور - الإنـاث) في أبعاد الطفو الأكاديمي (الفاعلية الذاتية، الاندماج الأكاديمي، العلاقة بين المعلم والطالب، الدرجة الكلية) لصالح الإناث، وعدم وجود فروق في أبعاد الطفو الأكاديمي (السيطرة غير المؤكدة، القلق) وبالتالي تحقق الفرض الثالث جزئيا. ويمكن تفسير تلك النتيجة في ضوء طبيعة كل من الذكور والإناث؛ حيث أن الإناث أكثر بحثا، والميل إلي العمل الجماعي والتعلم التعـاوني، وإقامـة علاقات طيبة مـع المعلمين والمعلمات والإدارة داخل المدرسـة، حيث يعتبر ذلك مصدر من مصـادر الثعور بالأمان أثناء 
مواجهة المشكلات والصـعوبات والتحديات والأزمـات، فعندما تتأخر الطالبـات عن حضـور الحصص الدراسية أو تتغيب لظرف ما أو عدم فهم جزء من منهج مقرر ؛ فإنها سرعان ما تسال

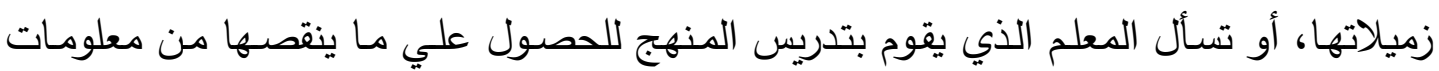
ومعارف وتستكملها، والذي بدوره يساعدها في ذلك.

كما يمكن تفسير الفروق بين الذكور والإنـاث في أبعاد الطفو الأكاديمي (الفاعلية

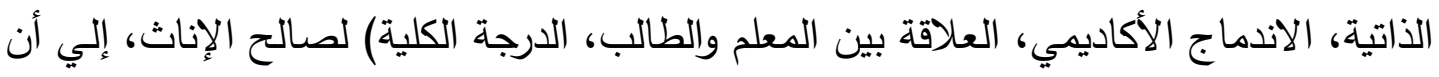

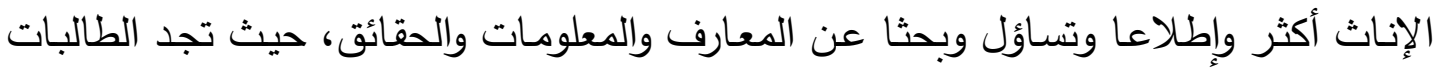

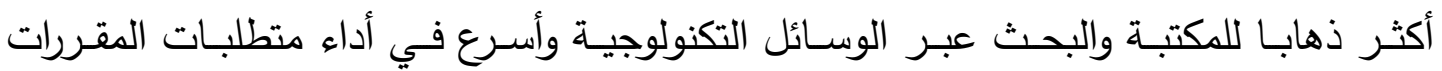
الدراسية، والاجتهاد في المذاكرة للحصول علي أعلي الدرجات والحصول علي المراكز الأولي

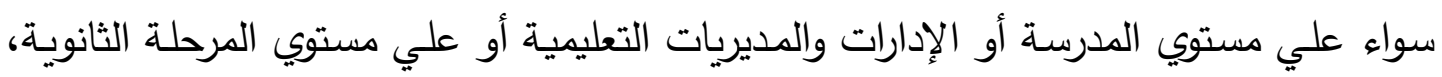
وهذا ما تؤكده نتائج المرحلة الثانوية علي مدار السنوات الماضية والتي تشير دائما إلي تفوق

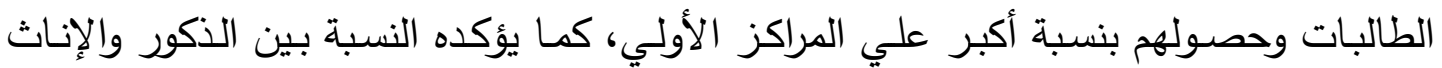

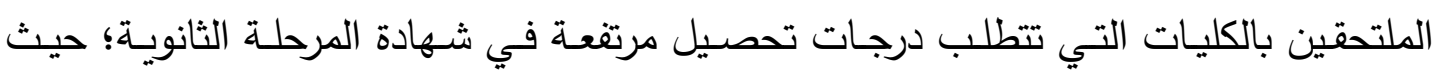
يلاحظ تفوق الإناث علي الذكور بتلك الكليات. كما تعمل الإناث علي تتمية كفاءتها وذاتها وقدراتها في مواجهة المواقف التعليمية، وعند إحساسها بعدم الثقة في معارفها ومعلوماتها حول موضوع ما تعمل علي بذل جهد أكبر في المذاكرة والتمكن من المقرر؛ لاستعادة ثقتها بنفسها، والقدرة علي اجتياز الاختبارات. واتفقت نتيجة الفرض الثالث ونتائج (Shafi, et al., 2018; Martin \& Marsh, 2019) والتي توصلت إلي وجود فروق في الطفو الأكاديمي بين الذكور والإنـاث لصـالح الإنـاث.

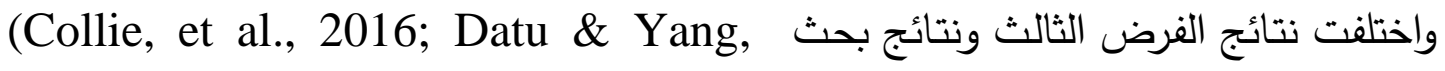
(2016; Mawarni, et al., 2019) في الطفو الأكاديمي بين الذكور والإناث لصالح الذكور .

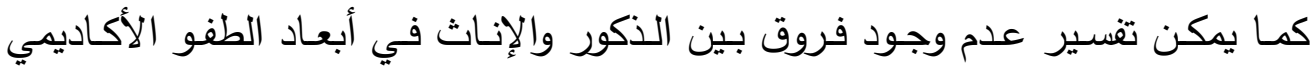
(السيطرة غير المؤكدة، والقلق) إلي طبيعة المرحلة العمرية وهي مرحلة مراهقة متأخرة، وما تتسم به توتر وقلق، وإلي طبيعة المرحلة الثانوية وهي مرحلة تحديد مصيرهم ومستقبلهم. ويتقق ذلك 
(Martin, et al., 2010; Rosemary, et al., 2019; Safoura \& Behzad, ونتائج (2019 والتي توصلت إلي عدم وجود فروق في الطفو الأكاديمي بين الذكور والإناث. كما يمكن تفسير نتيجة الفرض الثالث إلي طبيعة مرحلة الثانوية العامة؛ حيث يولئ يواجه

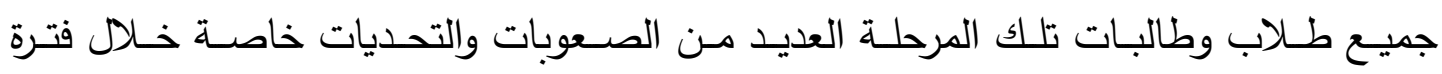

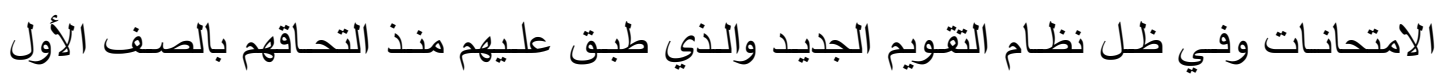

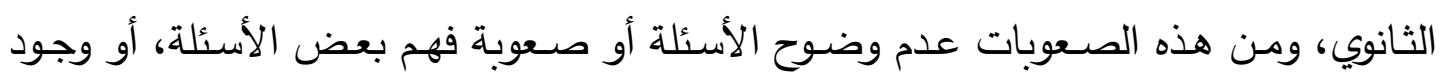

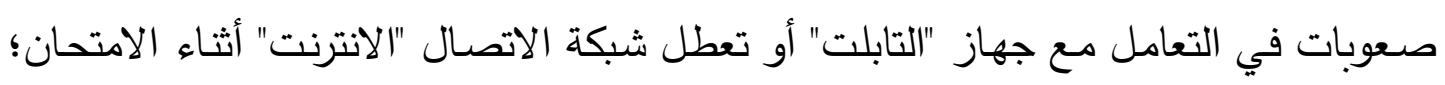
تلك الصعوبات ترفع من مستوي القلق لدي كل من الطلاب والطالبات، وبالتالي عدم السيطرة علي انفعالاتهم، والفشل في الإجابة علي بعض الأسئلة التي كان في مقدرتهم الإجابة عليها بسهولة ويسر في الظروف العادية. أشارت نتائج الفرض الرابع إلي وجود فروق ذات دلالة إحصائية بين متوسطي درجات

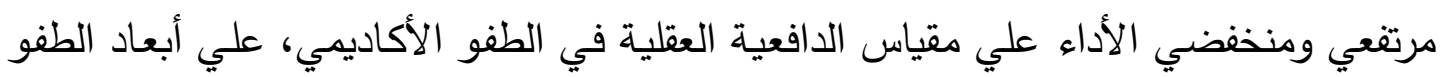

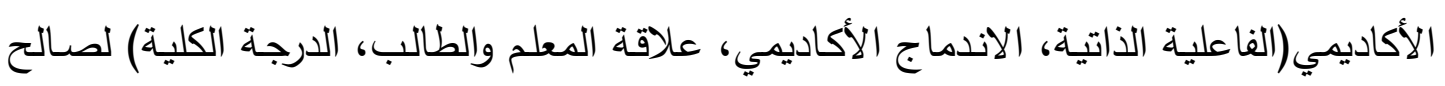
مرتفعي الدافعية العقلية، ووجود فروق في أبعاد الطفو الأكاديمي (السيطرة غير المؤكدة، التلق)

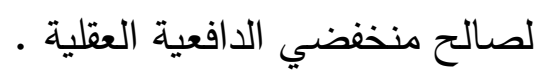
وتفسير ذلك أن الطلاب الذين يتمتعون بدافعية عقلية مرتفعة يتسمون بفاعلية ذاتية عند

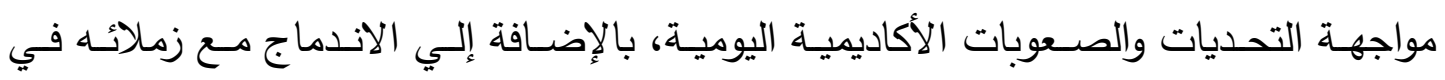
الأنشطة سواء داخل الفصل الدراسي أو خارجه، هذا إلي جانب تمتعه بعلاقات طيبة مع زملائه الإطية والمعلمين داخل المدرسة، ولديه مثابرة وحرص علي حضور حصصده الدراسية، وفهم محتوي

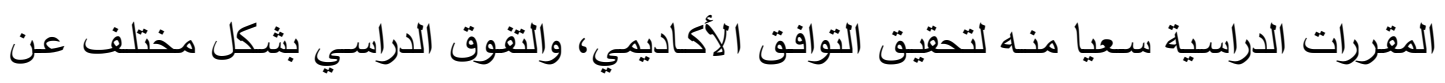

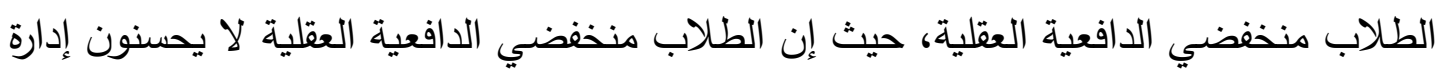
أوقاتهم بطريقة جيدة، ويؤجلون أعمالهم، وتنخفض لديهم الفاعلية الذاتية، ويميلون إلي العزلة التئل

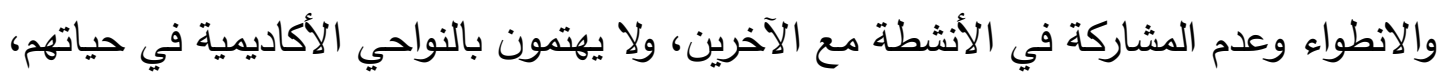

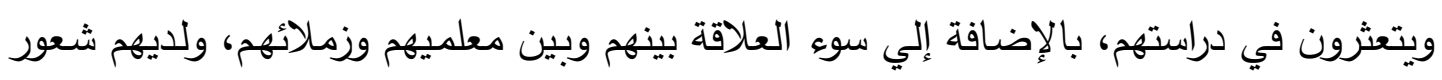

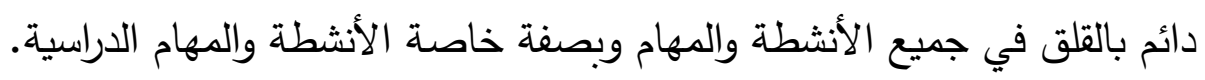


(Smith, 2016; Omaima, 2018; Shafi, et واتفتت نتيجة الفرض الرابع ونتائج (al., 2018; Alfonso \& Yang, 2019) الطلاب ذوي الدافعية العقلية المرتفعة يكون لديهم توجه ايجابي نحو التعلم، بمعني أنه يثن لتهن التعلم من أجل التعلم، ولديه القدرة علي استخدام مهارات التفكير بطريقة منطقية وموضوعية، وتقبل وجهات نظر الآخرين والاستفادة منها في إيجاد حلول إبداعية للمشكلات التي تواجهه.

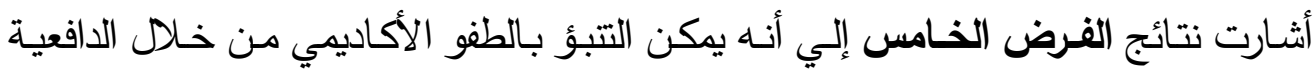

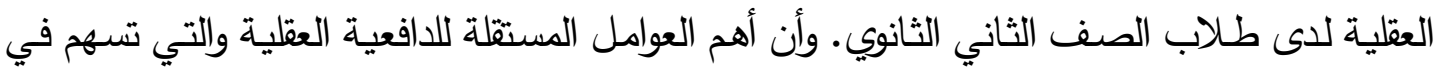

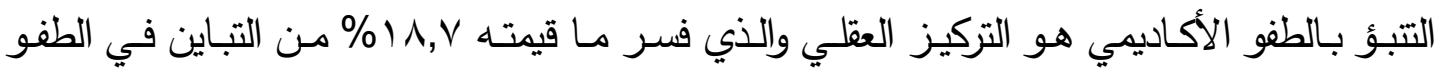

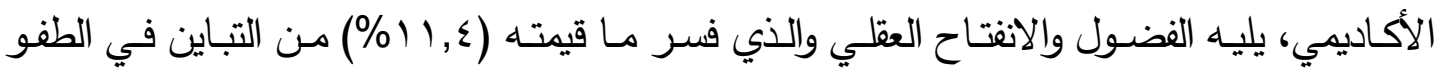
الأكاديمي، يليه حل المشكلات إبداعيا والذي فسر ما قيمته ب,؛؛ ٪ من التباين في الطفو الأكاديمي.

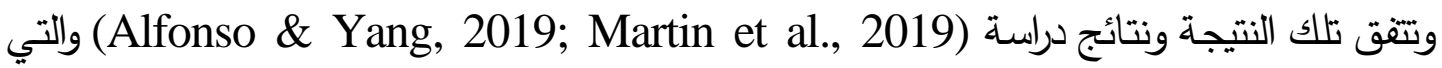
أثارت إلي أن الدافعية تسهم في التتبؤ بالطفو الأكاديمي. وتعتبر نتيجة الفرض الحالي طبيعية حيث إن الدافعية العقلية والطفو الأكاديمي من المتغيرات

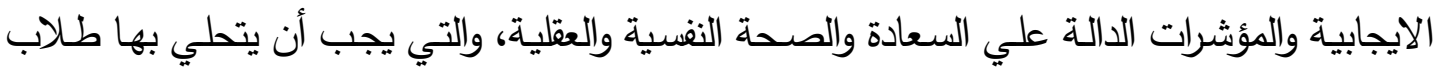
وطالبات المرحلة الثانوية، والذين هم قادة المستقبل ويلقى علي عاتقهم مهام عديدة لتحقيق طموحات المجتمع وتطلعاته (Hirvonen, Yli - Kivisto, Putwain, Ahonen \& Kiuru, 2019) ويمكن تفسير تلك النتيجة بأن تمتع طلاب المرحلة الثانوية بمستوي مرتفع من الدافعية

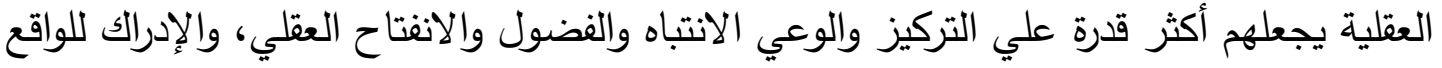
وقبلهم لأنفسه، مما يسهم بشكل كبير في تتمية كفاء اتهم وقدراتهم فاعليتهم الذاتية في مواجهة التهات

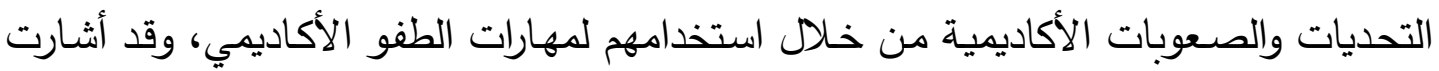
إلي ذلك نتائج بحث (Anderson, 2019) والتي توصلت إلي وجود فروق دالة إحصائيا في الرفاهية النفسية والصحة النفسية والعقلية بين القياسيين القبلي والبعدي لاي المجموعة التجريبية

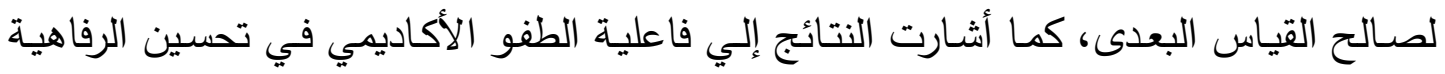
النفسية والصحة النفسية والعقلية. كما يمكن تفسير نتيجة الفرض الخامس بأن الدافعية العقلية تدفع الطلاب إلي الاهتمام بالأعمال والأنثطة التي يقومون بها، وتعطي أملا بالتوصل لأفكار جديدة وذات قيمة وهادفة لتهنة 
وبالتالي تجعل حياة الطلاب ممتعـة وأكثر مرونـة ومرحا، والاستمتاع بالتفكير في الأنثطة والمهام الأكاديمية من خلال التفاعل مع الآخرين.

\section{التــوصيــــات:}

في ضوء نتائج البحث الحالي تم وضع عدة توصيات هي:

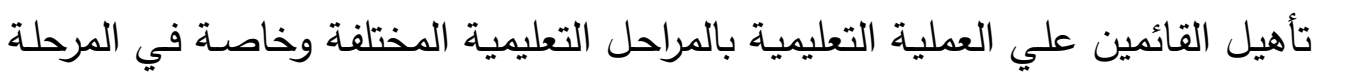

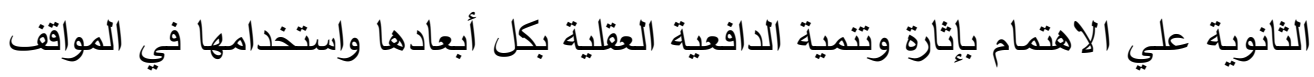

التعليمية بصفة خاصة ومواقف الحياة بصفة عامة.

ضرورة الاهتمام بالأنشطة التي تنمي الطفو الأكاديمي لدي الطلاب والطالبات مما يزيد

من فاعليتهم واندماجهم في الأنثطة التعليمية.

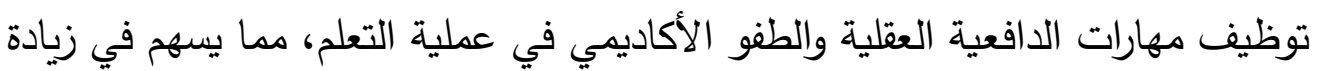
قدرة الطلاب والطالبات علي الانفتاح العقلي والتركيز والاندماج بفاعلية داخل الأنشطة التعليمية وتطبيق ما تعلموه في المواقف المختلفة، مما يسهم بشكل فعال في تحسين تحصيلهم الدراسي.

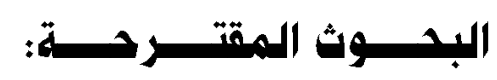

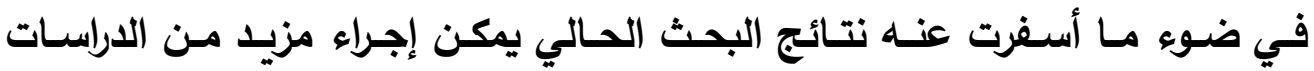

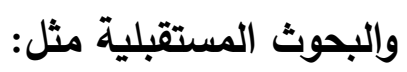

الطفو الأكاديمي وعلاقته بالدافعية العقلية والإنجاز الأكاديمي لدي طلاب الجامعة.

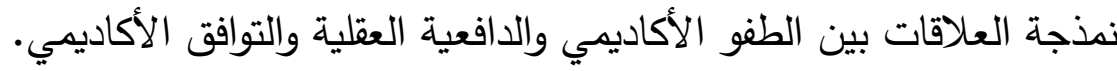

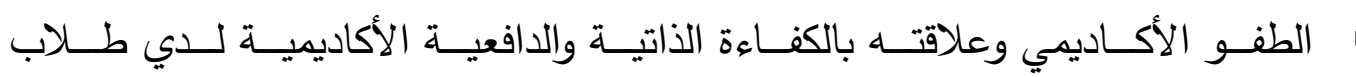
المرحلة الثانوية.

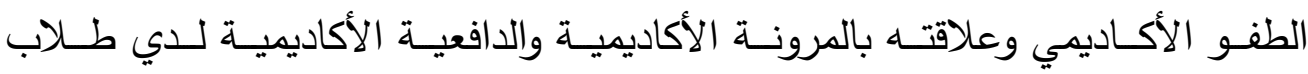

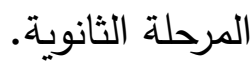
ه الطفو الأكاديمي وعلاقته بالدافعية الأكاديمية وتوجهات أهداف الانجاز . هور سمات الثخصية والمرونة الأكاديمية في التتبؤ بالطفو الأكاديمي. هور سمات الثخصية والدافعية العقلية في التتبؤ بالطفو الأكاديمي. 


\section{المـــراجـع}

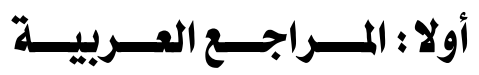

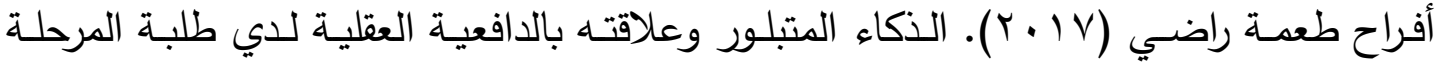

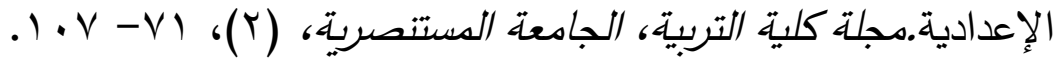

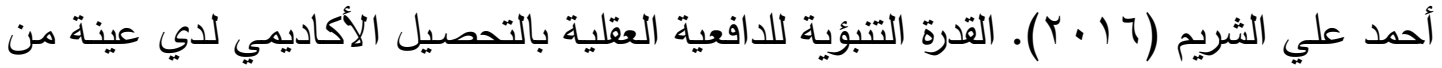
طلبة جامعـة القصيم، مجلة الدراسـات التربويـة والنفسية، جامعـة السلطان قابوس،

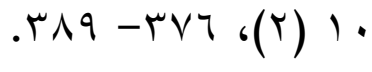

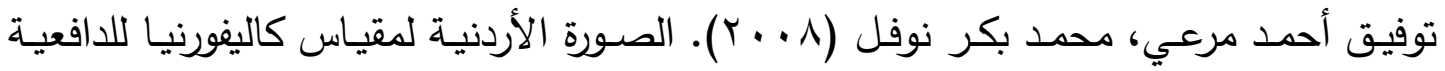
العقلية (دراسة ميدانية علي طلبة كلية العلوم التربويـة الجامعية الأنروا في الأردن،

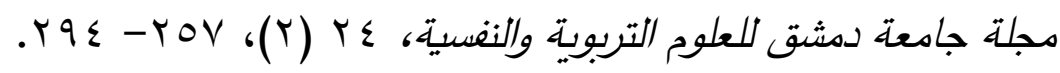

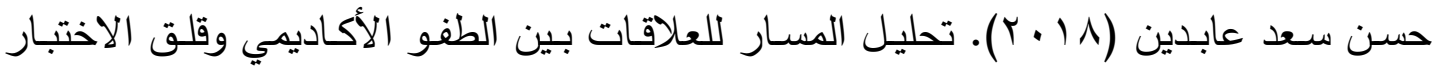
والثقة بالنفس والتوافق الأكاديمي لدي طلاب المرحلة الثانويـة. مجلة كلية التربية،

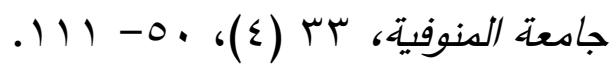

حسن عطيه الحميدي (9 ( ـ ( ). الدافعية العقلية لدى الطلبة الموهوبين بمحافظة جدة، مجلة كلية

$$
\text { التربية، جامعة أسيوط، هب (1)، 1) (1) }
$$

حسين أبو ريـاش، زهريـة عبد الحق (V . . r). علم النفس التربوي للطالب الجامعي والمعلم المداس. عمان: دار المسيرة للنشر والتوزيع والطباعة.

ديانـة إسماعيل كحيل (10 • ( ). السرعة الإدراكية البصـرية وعلاقتها بالدافعيـة العقليـة. رسالة ماجستير غير منشورة كلية التربية، جامعة دمشق.

إدوارد دي بونو (0 . . ب). الإبداع الجاد استخدام قوة التفكير الجانبي لخلق أفكار جديدة. ترجمة

$$
\text { باسمة النوري. الرياض: العبيكان. }
$$

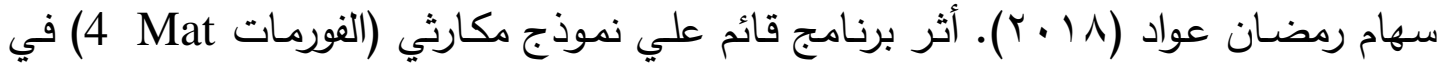
تتميـة الدافعيـة العقليـة لدي طالبـات جامعـة القصـيم. مجلـة العوم التربويـة، (ب)،

$$
. r 01-Y 19
$$


شيري مسعد حليم (9 ( ب). العلاقة بين الطفو الأكاديمي وتوجهات أهداف الإنجاز لاى طلبة

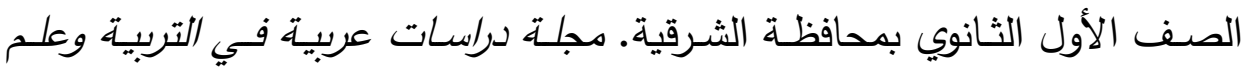

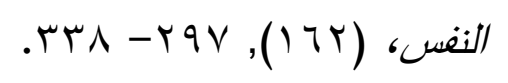

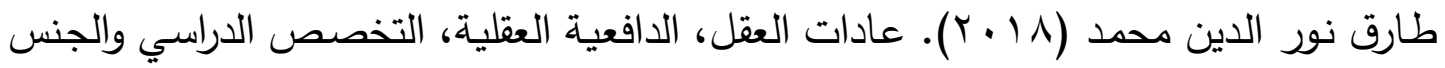
كتغيرات تتبؤيه لكفاءة التعلم الإيجابية لاى طلاب جامعة سوهاج. الدجلة التربوية،

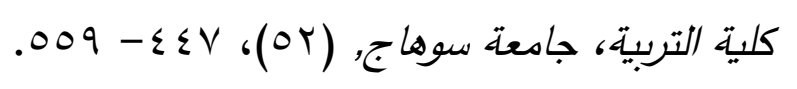

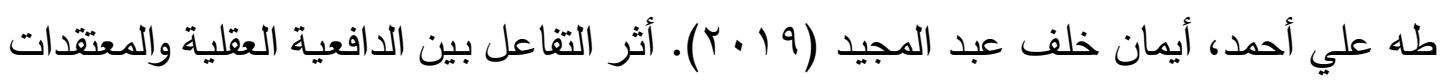

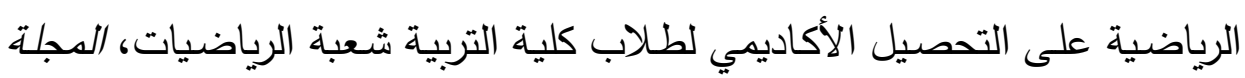

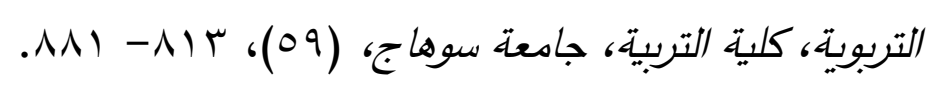

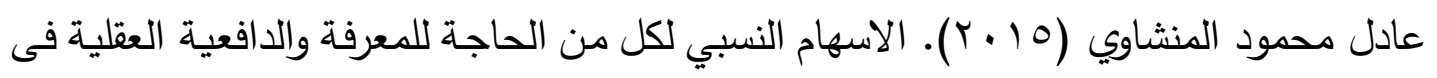
التتبؤ بالحكمة لدي طلبة كلية التربية، مجلة الجمعية المصرية للدراسات النفسية، النابية

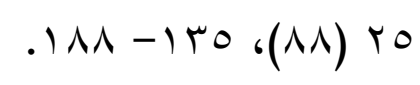

عماد عبد الرحيم الزغول ( • • (Y). علم النفس الدعرفي. عمان: دار المسيرة.

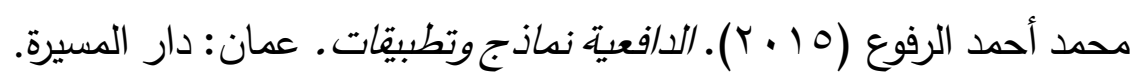

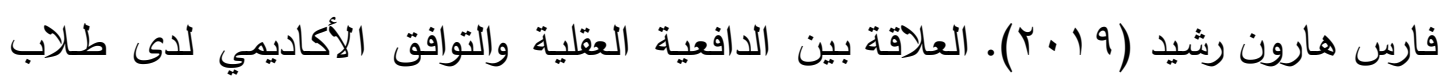

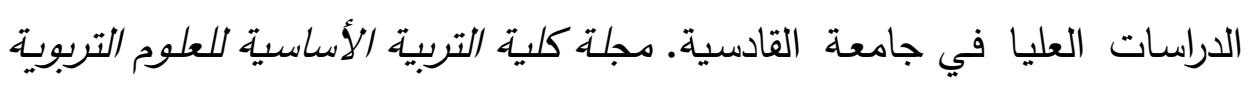

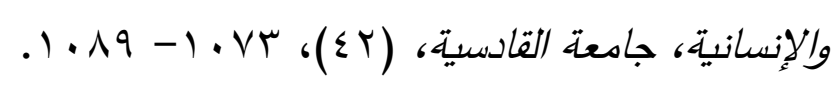

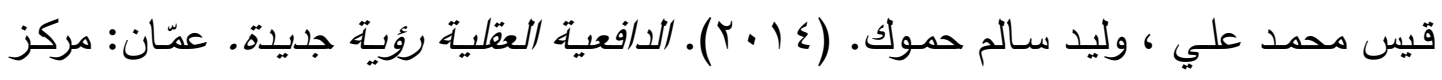

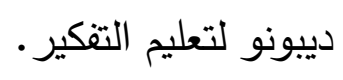

محمد بكر نوفل ( 9 . . Y). الإبداع الجاد مغاهيم وتطبيقات. عمّان: مركز ديبونو لتعليم التفكير.

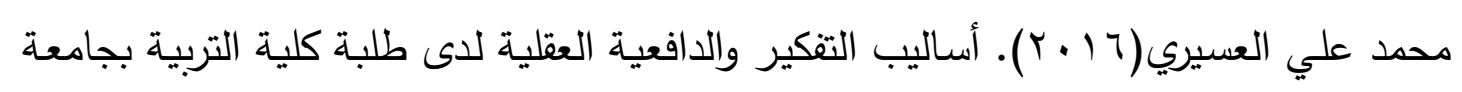

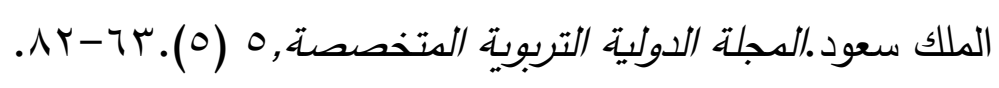

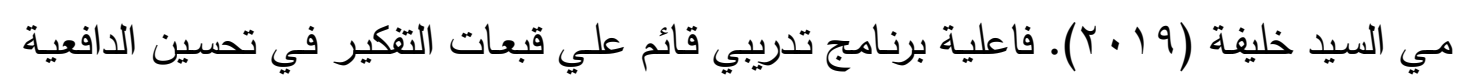

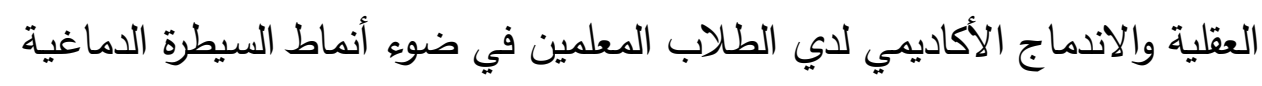

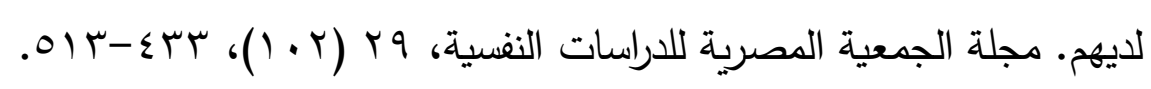


هشام حبيب الحسيني (9 ( ب ). أثر برنامج قائم علي مهارات التنكير الناقد وتحليل قوي المجال

والدافعية العقلية علي تتمية التفكير الابتكاري الاجتماعي، مجلة كلية التربية، جامعة الماتية

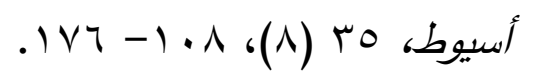

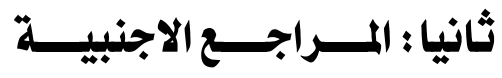

Alfonso, D., \& Yang, W., (2019). Academic buoyancy, academic motivation, and academic achievement among filipino high school students. Current psychology, 13, 1-11.DOI: 10.1007/s12144-01900358-y

Anderson, S. (2019). Promoting academic buoyancy as a pro-active approach for improving student mental health and wellbeing.', in Imagining Better Education: Conference Proceedings. Durham: Durham University, School of Education, Imagining Better Education. 33, 11-21.

Collie, R., Martin, J., Bottrell, D., Armstrong, D., Ungar, M., \& Liebenberg, L. (2016). Social support, academic adversity and academic buoyancy: aperson- centred analysis and implications for academic outcomes. An International Journal of Experimental Educational Psychology, 37 (5),550-564.

Collie, R, Martin, J., Malmberg, E., Hall, J., \& Ginns, P. (2017). Academic buoyancy, student achievement, and the linking role of control: A crosslagged analysis of high school students. British Journal of Educational Psychology, 87,113-130.

Colmar, S., Liem, G., Conner, J., \& Martin, J. (2019). Exploring the relationships between academic buoyancy, academic self-concept, and academic performance: A study of mathematics and reading among elementary school students. Educational Psychology, 39, 1068-1089.

Datu, D., \& Yuen, M. (2018). Predictors and Consequences of academic buoyancy: a Review of literature with implications foreducational psychological research and practice. Contemporary School Psychology, 22, 207-212.

Datu, D., \& Yang, W. (2016). Psychometric validity and gender invariance of the academic buoyancy scale in the Philippines: Aconstruct validation approach. Journal of Psychoeducational Assessment, 36(3), 278-283. 
Giancarlo, C., \& Facione, A. (1998). CM3 - California Measure of Mental Motivation - Test Manual. California Academic Press LLC

Giancarlo, C., \& Urdan, T. (2004). Assessing Secondary Students, Disposition toward Critical Thinking: Development of the California Measure of Mental Motivation. Academic Journal Education and Psychological Measurement, Santa Clara University, (64), 347-364

Heilat, M., \& Seifert, T. (2019). Mental motivation, intrinsic motivation and their relationship with emotional support sources among gifted and non-gifted Jordanian adolescents. Journal Cogent Psychology, 6 (1), 15- 37.

Hirvonen, R., Yli-Kivisto, L., Putwain, D., Ahonen, T., \& Kiuru, N. (2019) School-related stress among sixth-grade students associations with academic buoyancy and temperament. Journal of Learning and Individual Differences, 70, 100-108.

Jason, C., Tamzin, B., \& Roland, T. (2019). Academic Buoyancy in Second Level Schools: Insights from Ireland. Social and Behavioral Sciences, 197, 98-103.

Martin, J., \& Marsh, W. (2009). Academic resilience and academic buoyancy: Multidimensional and hierarchical conceptual framing of causes, correlates, and cognate constructs. Oxford Review of Education, 35(3), 353-370.

Martin, J., Colmar, H., Darey, A., \& Marsh, W. (2010). Longitudinal modeling of academic buoyancy and motivation: Do the 5CS' hold up over time. British Journal of Educational Psychology, 80, 473-496.

Martin, J. \& Burns, E. (2014). Academic buoyancy and adaptability: How to help students deal with adversity and change. In H. Street $\&$ N. Porter (Eds). Better than OK: Helping young people to flourish at school and beyond. Fremantle, WA: Fremantle Press, 28, 51-55.

Martin, J., Yu, K., Ginns, P., \& Papworth, B. (2017). Young people's academic buoyancy and adaptability: A cross-cultural comparison of China with North America and the United Kingdom. Journal of Educational Psychology, 37(8), 930-946. 
Martin, J., \& Marsh, W. (2019). Investigating the reciprocal relations between academic buoyancy and academic adversity: Evidence for the protective role of academic buoyancy in reducing academic adversity over time. International Journal of behavioral development, https://doi.org/10.1177/0165025419885027.

Martin, J., Hou, Y., Osborn, J., Yu, K., \& Zhan, X. (2019). academic Motivation, engagement, academic buoyancy, and adaptability: The roles of socio-demographics among middle school students in China. Measurement, 17, 119-133.

Mawarni, A., Sugandhi, N., Budiman, N., \& Thahir, A. (2019). Academic buoyancy of science student in senior high school: analysis and implications for academic outcomes. Journal of Physics: Conference Series, 1280, 032046 doi:10.1088/17426596/1280/3/032046.

Omaima, G. (2018).Academic buoyancy, motivation, and academic achievement of (first-year) college students. Journal of Education Science, 26, (4), 21 -34

Piosang, T. ( 2016).The Development of Academic Buoyancy Scale for Students (ABS-AS). The assessment, Handbook, 12, 13- 44.

Putwain, D., Connors, L., Symes, W., \& Douglas-Osborn, E. (2012). Is academic buoyancy anything more than adaptive coping?. Anxiety stress \& Coping, 25(3), 349-358.

Putwain, D., Chamberlain, S., Daly, A., \& Sadreddini,S. (2015). academic buoyancy students are less anxious about and perform better in high-stakes examinations. British Journal of educational psychology, 85, 247-263.

Rohinsa, M., Cahyadi, S., Djunaidi, A., \& Iskandar, Z. (2019). The Role of Personality Traits in Predicting Senior High School Students' Academic Buoyancy. The Journal of Social Sciences Research, 5(9), 1336-1340. 
Rosemary, A., Wawire, Ch., \& Doyne, M. (2019). Relationship between Self-efficacy and Academic Buoyancy among form three Students in Selected Secondary Schools in Migori County, Kenya. International. Journal of Research and Scientific Innovation, 6 (12), 161- 170.

Safoura, J., \& Behzad, G. (2019). Academic buoyancy in higher education Developing sustainability in language learning through encouraging buoyant EFL students. JARHE, 11(2), 162 -177.

Shafi, A., Hatley, T., Millican, R., \& Templeton, S. (2018). The Role of Assessment Feedback in Developing Academic Buoyancy. Assessment and Evaluation in Higher Education, 43 (3), 415-427.

Smith, M. (2016). Forget Resilience, it's about academic buoyancy. Essential Weekly Intelligence for the education professional, (19), 28-34.

Wurf,G. \& Groft-piggin,L.(2015). Predicting the academic achievement of first-year, pre-service teachers: The role of engagement, motivation, ATAR, and emotional intelligence. Asia Pacific Journal of Teacher Education, 45(1), 75-91.

Yasmine, A., (2019). Music shown to significantly improve mental motivation. Journal of Science \& Technology, 24, 34-38. 